\title{
Urbanization, environmental stabilization and temporal persistence of bird species: a view from Latin America
}

\author{
Lucas Matías Leveau Corresp. 1 \\ ${ }^{1}$ Facultad de Ciencias Exactas y Naturales, IEGEBA, Universidad de Buenos Aires, Departamento de Ecología, Genética y Evolución, Ciudad Autónoma de \\ Buenos Aires, Argentina \\ Corresponding Author: Lucas Matías Leveau \\ Email address: leveau@ege.fcen.uba.ar
}

Background. A scarcely studied consequence of urbanization is the effect of temporal stabilization of the environment on bird communities. This alteration is thought to dampen environmental variations between day and night, seasons and years, promoting a temporal persistence of bird composition in urban areas. The aim of this study was to review current evidence of temporal stabilization of biotic and abiotic factors in urban environments and the potential effects of such stabilization on temporal variation of bird species presence at different temporal scales.

Methods. I selected the literature by searching published articles and book chapters using Scopus and Google scholar. I only included articles that compared the temporal variation of bird composition or resources between different levels of urbanization.

Results. In general, there is evidence of temporal stabilization of abiotic and biotic factors at the three time scales considered. At the diurnal scale, the main factor considered was artificial light in the context of light pollution. At the seasonal and interannual scales, several case studies found a smaller temporal variation of primary productivity in urban than in natural and rural areas. Bird species composition showed more stabilization in urban environments at the three temporal scales: 1) several case studies reported bird activity at night, associated with artificial light; 2) studies in urban parks and along urbanization gradients showed smaller seasonal variation of bird composition in the more urbanized areas; and 3) in general, case studies along urbanization gradients showed smaller interannual variation of bird composition in the more urbanized areas, although some studies showed no relationships or opposite trends than expected.

Discussion. The published evidence suggests that urban areas dampen the natural cycles at several temporal scales. The stabilization of biotic and abiotic factors, such as light, temperature, food and habitat structure, is desynchronized from natural diurnal, seasonal and interannual cycles. However, there is a dearth of long-term comparisons of bird composition and studies that simultaneously analyze the relationship between resources 
and bird composition stabilization at the seasonal and interannual scales. More research is needed in the Southern hemisphere, where there is a lack of studies dealing with the seasonal and interannual variations of primary productivity along urbanization gradients and nocturnal activity of bird species. A future research agenda should include differentiation of spatial and temporal homogenization of avifaunas. 


\section{Urbanization, environmental stabilization and temporal persistence}

\section{2 of bird species: a view from Latin America}

3

4

5

6 Lucas Matías Leveau

7 Departamento de Ecología, Genética y Evolución, Facultad de Ciencias Exactas y Naturales,

8 Universidad de Buenos Aires - IEGEBA (CONICET-UBA), Ciudad Autónoma de Buenos Aires,

9 Argentina

10

11

12 Corresponding author

13 Lucas M. Leveau

14 E-mail: leveau@ege.fcen.uba.ar

15 


\section{Abstract}

17 Background. A scarcely studied consequence of urbanization is the effect of temporal stabilization of the environment on bird communities. This alteration is thought to dampen environmental variations between day and night, seasons and years, promoting a temporal persistence of bird composition in urban areas. The aim of this study was to review current evidence of temporal stabilization of biotic and abiotic factors in urban environments and the potential effects of such stabilization on temporal variation of bird species presence at different temporal scales.

Methods. I selected the literature by searching published articles and book chapters using Scopus and Google scholar. I only included articles that compared the temporal variation of bird composition or resources between different levels of urbanization.

Results. In general, there is evidence of temporal stabilization of abiotic and biotic factors at the three time scales considered. At the diurnal scale, the main factor considered was artificial light in the context of light pollution. At the seasonal and interannual scales, several case studies found a smaller temporal variation of primary productivity in urban than in natural and rural areas. Bird species composition showed more stabilization in urban environments at the three temporal scales: 1) several case studies reported bird activity at night, associated with artificial light; 2) studies in urban parks and along urbanization gradients showed smaller seasonal variation of bird composition in the more urbanized areas; and 3) in general, case studies along urbanization gradients showed smaller interannual variation of bird composition in the more urbanized areas, although some studies showed no relationships or opposite trends than expected.

37 Discussion. The published evidence suggests that urban areas dampen the natural cycles at several temporal scales. The stabilization of biotic and abiotic factors, such as light, temperature, 
39 food and habitat structure, is desynchronized from natural diurnal, seasonal and interannual

40 cycles. However, there is a dearth of long-term comparisons of bird composition and studies that

41 simultaneously analyze the relationship between resources and bird composition stabilization at

42 the seasonal and interannual scales. More research is needed in the Southern hemisphere, where

43 there is a lack of studies dealing with the seasonal and interannual variations of primary

44 productivity along urbanization gradients and nocturnal activity of bird species. A future

45 research agenda should include differentiation of spatial and temporal homogenization of

46 avifaunas.

47

48 


\section{Introduction}

51 Urbanization has many impacts on natural and semi-natural environments; urban expansion

52 promotes fragmentation of ecosystems, perforation through the creation of different urban areas,

53 alteration of biogeochemical cycles, the occurrence of the urban heat island phenomenon and

54 pollution (Miller et al., 2001, Grimm et al., 2008; Shanahan et al., 2014). These environmental

55 changes have impacts on the spatial dynamics of species, producing significant declines in

56 species diversity in highly urbanized areas and significant changes in bird composition (Faeth et

57 al., 2011; Suarez-Rubio et al., 2011). The uniform structure of urban areas across the world

58 promotes the invasion of a reduced number of cosmopolitan species, leading to biotic

59 homogenization (McKinney, 2006). A scarcely explored consequence of urbanization is the temporal stabilization of biotic and abiotic factors, which may induce a decline of the temporal

61

62

63

64

65

66

67

68

69

70

71 beta diversity of biological communities.

Birds are one of the most widely studied taxa in urban environments because they are easily observable and respond to environmental changes (Lepczyck et al., 2017). Birds can be used as indicator species of habitats that support other species and, therefore, contribute to the understanding of the impact of urbanization on biodiversity (Gil and Brumm, 2014;Lepczyck et al., 2017). In addition, birds are associated with ecosystem services and disservices (Sekercioglu, 2006; Lyytimäki et al., 2008; Wenny et al., 2011; Belaire et al., 2015). In natural areas, biotic factors such as predator presence or food availability, and abiotic factors, such as the variation of light throughout the day or seasonal changes in rain or temperature, induce temporal changes in species composition, favoring the coexistence of species through temporal segregation and an increase in beta diversity (Schoener, 1974; Herrera, 
72 1978; Kronfeld-Schor and Dayan, 2003; Uchida and Ushimaru, 2015). For example, light

73 variation during the day allows the coexistence of diurnal and nocturnal raptors in a given area,

74 reducing their agonistic interactions (Jaksić, 1982). Seasonal fluctuations in the amount of

75 resources favor the coexistence of resident and migrant species in temperate regions (Hurlbert

76 and Haskell, 2003; Dalby et al., 2014).

77 Recently, several authors noted that urban areas may promote a significant loss of

78 temporal heterogeneity of biological diversity (Suhonen et al., 2009; Leveau and Leveau, 2012;

79 La Sorte et al., 2004; Leveau et al., 2015; Uchida et al., 2018), as a consequence of the

80 stabilization of biotic and abiotic factors. Dampening of temporal variation in resources may

81 influence bird community composition by favouring the temporal persistence of bird species

82 capable of exploiting such resources, the so-called urban exploiters and adapters (see Blair,

1996). Furthermore, stabilization of habitats and resources may promote the local extinction of

84 those species adapted to temporal changes of resources and natural disturbances (Gliwicz et al.,

1994; Luniak, 2004; Shochat et al., 2006; Duckworth, 2014; Parris, 2016; Pickens et al., 2017).

For example, the Bachman's sparrow (Peucaea aestivalis) is related to fire disturbance, and a

87 decline in its numbers is predicted due to projected urban growth (Pickens et al., 2017). The

ultimate consequences of these changes would be the local dominance and regional expansion of species benefited by the stabilization of resources in urban environments (Shochat et al., 2006;

Duckworth, 2014; Parris, 2016).

Stabilization of urban environments needs to be addressed at several temporal scales because urbanization may promote the dampening of environmental conditions between day and

93 night, seasons and years. For example, the profound alteration produced by artificial light in

94 urban environments at night is associated with nocturnal activity of birds (Rejt, 2004; La, 2012). 
95 The reduced annual variation of food resources in urban areas has a negative effect on the

96 presence of migratory species and favors the permanence of resident bird species (Leveau et al.,

97 2015; Leveau and Leveau, 2016). Moreover, the management of interannual natural

98 disturbances, such as flood or fire, in urban areas may lead to the extinction of bird species associated with the changes in the landscape induced by such disturbances (Pickens et al., 2017). Temporal stabilization of the environment in urban areas may induce a temporal homogenization of bird communities; under this scenario, humans perceive a similar bird composition at any time

102 and can be disconnected from the natural rhythms of nature (Leveau et al., 2015; Leveau and 103 Leveau, 2016).

Most reviews about urban bird ecology were conducted in developed countries (Chace and Walsh, 2006; Shanahan et al., 2014; Reynolds et al., 2017). Cities in developing regions, such as in Latin America, have socioeconomic and morphological contrasts with cities in developed countries. For example, Latin American countries have lower per capita income, higher socioeconomic inequality, and more compact and dense cities (Huang et al., 2007) than developed countries. These socioeconomic and morphological factors could affect bird communities; therefore, there is a need to conduct research in developing countries. In this review, factors that were stabilized by urbanization and that may influence the

112 temporal dynamics of bird composition were categorized as biotic and abiotic (Hooper et al., 113 2005; Pau et al., 2011; Beninde et al., 2015), such as food and artificial light, respectively. This 114 classification allows us to determine the relative role of biotic or abiotic factors at the analyzed 115 temporal scales. Therefore, the specific aims of this synthesis were to: 1) review evidence of 116 temporal stability in biotic and abiotic factors influencing birds in urban environments across 117 different temporal scales; and 2) assess the impact of urbanization on temporal persistence of 
118 bird species composition at different temporal scales. Finally, possible lines of research are 119 recommended.

\section{Survey methodology}

122 The first step in the selection of literature for this review consisted of searching for studies on the

123 temporal variation of bird communities and the resources they use, using keywords such as

124 "interannual", "seasonal", "nocturnal" coupled with "urban" and "bird", and "interannual", 125 "seasonal", "nocturnal" coupled with "fruits", "insects" "resources" and "vegetation phenology"

126 (see Supplementary material, Table S1). I used Google Scholar during December 2017 and

127 reviewed the first 300 returns ordered by relevance for each keyword, and the Scopus database in

128 March 2018 for papers published since database inception, including those terms in the title,

129 abstract and keywords. Moreover, I received weekly Google scholar alerts about papers

130 published with the terms "urban" and "birds". I included only articles that compared temporal

131 variation of bird composition or resources between different levels of urbanization (urban vs

132 suburban, urban vs rural, etc.) or different levels or environmental conditions related to

133 urbanization (impervious cover, light and noise levels). I did not include studies that analyzed

134 long-term dynamics of bird communities in urban parks or suburban areas that also underwent

135 changes in local habitat structure and landscape composition (for example, Walcott, 1974;

136 Recher and Serventy, 1991). In the case of nocturnal activity of diurnal birds, I took into account 137 cases of birds singing, feeding or doing both activities.

138

139 3. Temporal stabilization of resources and habitats

140 3.1. Diurnal scale 
141

142

143

144

145

146

147

148

149

150

151

152

153

154

155

156

157

158

159

160

161

162

163

\subsubsection{Abiotic factors}

Undoubtedly, artificial lighting is the most notable factor altering the natural day-night cycle in urban areas, exerting negative effects on wildlife (Navara and Nelson, 2007). For example, Black-tailed godwits (Limosa limosa) avoided illuminated areas when selecting nest sites (Longcore and Rich, 2004). However, some bird species may take advantage by extending their feeding times (Deviche and Davies, 2014; see examples below). Global maps indicate that the areas most impacted by artificial lighting are the most urbanized ones, such as east North America and Europe (Cinzano et al., 2001; Longcore and Rich, 2004). The greatest increase of light pollution from 1992 to 2012 occurred in Mediterranean-climate ecosystems and temperate ecorregions (Bennie et al., 2015). Within cities, artificial lighting increases with rising urbanization level (Kyba et al., 2012; Hale et al., 2013; Katz and Levin, 2016), being more intense in commercial (Lim et al., 2018; Ma, 2018) than in residential areas. In Berlin, most of zenith directed light comes from streets, including direct and scattered lights from lamps, automobile headlights, advertising lights located in the street area and, to some extent, light from building facades (Kuechly et al., 2012). The next land use with high light emissions was the commercial/industrial/service and public service area. Zheng et al. (2018) found that main roads, commercial and institutional areas were brightly lit in Hangzhou (China), whereas residential, industrial and agricultural areas were dark at night. In Flagstaff (USA), 33\% of uplight was found to arise from sports lighting; when sport lighting was off, commercial and industrial lighting accounted for $62 \%$ (Luginbuhl et al., 2009). In Reykjavik (Island), almost 50\% of artificial light at night came from street lights (Hiscocks and Gudmundsson, 2010).

The urban heat island phenomenon may impact the day-night variation of temperature. Lazzarini et al. (2015) found that day-night difference of land surface temperature (LST) was 
164 lower in urban than in natural areas of desert cities in North America, Africa and the Middle 165 East.

166

167

\subsubsection{Biotic factors}

168

Food availability at night is another factor promoting nocturnal activity of diurnal bird species

169

(Fig. 1). Artificial lighting attracts invertebrates, which are more abundant under street lights than in patches between lights (Scanlon and Petit, 2008; Davies et al., 2012; but see Farnworth et al., 2018). By attracting invertebrates, street lights provide potential food resources for insectivorous birds that extend their activity time after sunset (Fig. 1). However, the attraction of invertebrates by lamps depends on the type of light (Eisenbeis and Hänel, 2009; Longcore et al., 2015); Eisenbeis and Hänel (2009) found that mercury lamps attracted more insects than sodium lamps. In aquatic environments, artificial light at night has been shown to alter the activity of diurnal fish species, allowing a constant activity of the Baunco fish (Girella laevifrons) through

177 the day and night (Pulgar et al. 2018). Moreover, diurnal raptors may exploit alternative food 178 resources available at night at sites with artificial light, such as bats (Mikula et al., 2016).

179 Finally, pedestrian traffic after sunset may provide, directly or indirectly, food resources for omnivorous bird species in urban centres.

\subsection{Seasonal scale}

\subsubsection{Abiotic factors}

184 Abiotic factors altered by urbanization were mainly temperature and wind. Temperature may

185 influence birds directly via the urban heat island phenomenon (Rizwan et al., 2008), by

186 increasing temperatures during winter and favoring bird presence (Leston and Rodewald, 2006). 
187 The urban heat island may have an indirect effect on seasonal stabilization of resources used by

188 birds by favoring an extended growing season of vegetation (see below Biotic factors).

A number of studies analyzed the seasonal variation of temperature along urbanization

190 gradients. However, most of them were concetrated in China, especially in Beijing

191 (Supplementary material, Table S2). The majority of studies were concentrated between 2010

192 and 2018 (22 of 24 studies), and the most widely used remote sensors were the Moderate

193 Resolution Imaging Spectroradiometer (MODIS) and Landsat 5 and 7, although both have

194 contrasting spatial resolutions (1000 and 60-120 m, respectively). These remote sensors

195 measured the land surface temperature (LST). In general, studies found that urban areas had a

196 higher seasonal LST variation than rural or natural areas. Other studies that compared urban with

197 desert or sand dune areas showed a smaller seasonal change of LST in urban areas. This

198 heterogeneity in results suggest that seasonal fluctuations of LST associated with urbanization

199 are context-dependent. Even within a given study area, results vary for different land uses

200 compared to the urban area. For example, Meng et al. (2009) found that the seasonal change of

201 LST was higher in the urban area than in the forest, but seasonal change of LST was bigger in

202 the grassland than in the urban area.

203

Seasonal fluctuation of wind intensity may be altered by urbanization. A study in Phoenix

204 (USA) showed that in urban areas, wind speed was significantly reduced, contributing to

205 increased plant growth and accumulated biomass (Bang et al., 2010). This increase in plant

206 biomass can have positive impacts on higher trophic levels, such as birds. Similarly, a reduced

207 wind speed may have direct positive effects on the reproductive success of birds by reducing the

208 probabilities that eggs and nestlings fall from the nest (Leveau pers. obs.). 
210

211

212

213

214

215

216

217

218

219

220

221

222

223

224

225

226

227

228

229

230

231

232

\subsubsection{Biotic factors}

Biotic factors stabilized by urbanization at the seasonal scale included vegetation, abundance of arthropods and food supplied by humans. Abiotic factors, such as temperature and irrigation, also affected the extended growing season of vegetation.

Evidence of altered seasonal patterns of resources came mainly from data of leaf and flowering phenology and vegetation indices obtained from remote sensors; those data are mainly indicators of the net primary productivity. Most studies were conducted in the Northern Hemisphere, mainly in USA and China; and were concentrated in the 2010-2018 period (10 out of 12 studies) (Supplementary material, Table S3). The most widely used remote sensor was MODIS, which produces the MOD13Q1 database that contains images of the Normalized Difference Vegetation Index (NDVI) and the Enhanced Vegetation Index (EVI). These images are produced every 16 days and are freely available. Several studies found an extended growing period of vegetation in urban environments, associated with the increase in temperature induced by the urban heat island (Imhoff et al., 2000; Luo et al., 2007; Buyantuyev and Wu, 2012; Zhou et al., 2016). Other studies showed a smaller seasonal change of primary productivity in urban areas than in natural and rural areas (Coops et al., 2009; Coetzee and Chown, 2016; Leveau et al., 2018). Along the urban-rural gradient of Mar del Plata (Argentina), the lowest seasonal change of primary productivity was related to high percentage cover of buildings and vegetation typical of residential houses (lawn, shrubs and trees), whereas the greatest seasonal change of primary productivity was related to non-managed herbaceous vegetation and crops (Figure 2). Neil and $\mathrm{Wu}$ (2006) conducted a review about the effect of urbanization on plant phenology and found that spring-blooming plants tended to bloom earlier in a variety of ecosystems in North America, Europe and China. Moreover, ffrench-Constant et al. (2016) 
233 related budburst data from four deciduous trees to night-time lighting using satellite data as well

234 as spring temperature. The authors found that tree budburst occurred 7.5 days earlier in brighter 235 areas, which indicated the presence of urban areas in United Kingdom. In Florence (Italy), light 236 exposure from luminaires extended the greening of leaves by nearly 20 days (Massetti 2018).

237 Due to a warmer microclimate, plants had less frost damage in urban areas of Phoenix (USA) 238 than in the desert and, therefore, green leaves were more persistent in urban areas (Bang et al., 239 2012). In the same city, plants flowered for a longer period than their desert counterparts, 240 promoting a higher abundance of pollinators in urban areas (Neil et al., 2014). In South Korea, 241 four species of plants extended their flowering period in the most urbanized areas (Jeong et al., 242 2011). Comber and Brunsdon (2015) found that the first flowering occurred earlier in urban 243 areas of the United Kingdom than in other land uses, but the effect of urbanization varied 244 spatially, suggesting the need for spatially explicit analysis. Gorton et al. (2018) found that the 245 plant Ambrosia artemissifolia flowered earlier in urban than in rural habitats of Minneapolis 246 (USA), and attributed this asynchronous flowering to genetic differences between populations.

247 On the other hand, Davis et al. (2016) found that native trees in Sydney (Australia) flowered 248 longer in streets than in remnant and continuous forests, providing more food resources to 249 nectarivorous birds. Nectar and fruits may be available during seasons when they would be 250 naturally absent or scarce due to the planting of ornamental trees (Williams and Karl, 1996; 251 Corlett, 2005; Leston and Rodewald, 2006; Williams et al., 2006; Montaldo, 1984; Leveau, 252 2008; Leveau and Leveau, 2011; Davis et al., 2015; Gray and van Heezik, 2016) (Figure 1). On 253 the other hand, a couple of studies found a greater seasonal change of primary productivity and a 254 shorter growing season in an urban area than in a forest (Chang et al. 2011; Mishra and 255 Chaudhuri 2015; Supplementary material, Table S3), suggesting that urbanization impacts on 
256 seasonal dynamics of primary productivity are biome-dependent.

257 Irrigation, fertilizer application and pruning, and the planting of perennial tree species

258 such as Pinus sp. and Eucalyptus sp. may stabilize the seasonal dynamics of primary productivity

259 in urban areas compared to agricultural and natural areas (González-Garcia and Gómez Sal,

260 2008; Loram et al., 2011; Buyantuyev and Wu, 2012; Leong and Roderick, 2015) (Figure 1). The

261 longer period of growing and stability of vegetation in cities may impact other organisms, such

262 as invertebrates, especially if vegetation exerts bottom-up control on them (Leong and Roderick,

263 2015). Therefore, there would be more food resources available to birds throughout the year.

264 Studies that analyzed the seasonal variation of arthropod abundance and frequency along

265 urbanization gradients were mainly concentrated in the $2010-2018$ period $(80 \%, \mathrm{n}=20)$ and

266 were equally distributed in North America, Europe, Asia, and South America (Supplementary

267 material, Table S4). In general, there was a lower seasonal change in abundance of arthropods in

268 urban than in rural or natural areas. Some studies showed a lower variation in intermediate levels

269 of urbanization and industrial areas (McIntyre et al., 2001; Mulieri et al. 2011). Other studies

270 found a similar variation between urbanization levels (Carbajo et al., 2004) or a higher variation

271 in urban areas (Baruah and Dutta, 2013).

272 The provision of bird feeders with grains or nectar is an important stabilizing factor for

273 birds in urban areas, but they are mainly distributed in cities of developed countries (Jones and

274 Reynolds, 2008) (Figure 1). In Europe, bird feeding was more frequent in Scandinavian countries

275 and Ireland (Thompson et al., 1993). Compared with rural areas, the number and type of food

276 provided by humans is higher in urban areas (Tryjanowski et al., 2015). While urban areas are

277 characterized by large numbers of bird tables and human food provided on the ground, rural

278 areas showed a more frequent use of pig fat and/or skin sometimes mixed with some seeds and 
279 prepared as a block or ball (Tryjanowski et al., 2015). Within each city, bird feeding was more

280 frequent in small parks (Thompson et al., 1993; Gaston et al., 2007) and in feeders located at

281 high altitude (Thompson et al., 1993). Moreover, several authors showed that bird feeding was

282 related to socioeconomic and demographic factors (Lepczyk et al., 2004; Arizmendi et al., 2008;

283 Fuller et al., 2008; Davies et al., 2012; Sonne et al., 2016; Ramírez-Segura, 2016). For example,

284 the provision of seeds and artificial nectar is related to high socioeconomic levels (Davies et al.,

285 2012; Ramírez-Segura, 2016). Over the year, food provided by humans was most frequent during

286 winter, although food composition did not vary (Cowie and Hinsley, 1988). Finally, the presence

287 of landfills may be a constant source of food for gulls, ibis and raptors throughout the year

288 (Yorio and Giaccardi, 2002; Martin et al., 2010; Marateo et al., 2013; Oro et al., 2013; Plaza and

289 Lambertucci, 2017).

290

291

\subsection{Interannual scale}

292

\subsubsection{Abiotic factors}

293 Natural disturbances that strongly impact vegetation structure and bird communities, such as

294 hurricanes, tornados or fire (Liu et al., 1997; Waide, 1991; Yaukey 2012), may be reduced or

suppressed in urban areas. Kingfield and Beurs (2017) found that tornado impact on NDVI was

lowest in the most densely urbanized areas in USA. Fire activity was minimal at the edge of

urban areas in the Sierras chicas (Argentina) and North Carolina (USA) (Argañaraz et al., 2015;

Pickens et al., 2017). However, Branoff (2018) found no impacts of urbanization on mangroves vegetation resistance to hurricanes. On the other hand, floods may be increased by urbanization (Hollis, 1975; Konrad, 2003; Jacobson, 2011). 
302 scarce. A study from China showed that interannual variation in LST was higher in urban areas

303 than in forests (Zhao et al. 2009).

304

305

\subsubsection{Biotic factors}

306 A few studies from North America provided remote sensing data and suggested that urban areas

307 have a lower interannual variability of primary productivity than natural areas (Shochat et al., 308 2004; Leong and Roderick, 2015). Therefore, habitat structure and food resources for birds may 309 be temporally more stable in urban than in rural areas. In addition, Bang et al. (2012) found that 310 the impact of interannual variability of precipitation had greater effects on plant growth and 311 arthropod abundance in desert than in urban areas.

312 Activities such as maintaining vegetation or using fertilizers and pesticides may stabilize 313 the interannual habitat structure and primary productivity of residential areas (Lepczyk et al., 314 2004) (Figure 1). Furthermore, using and maintaining nest boxes in backyards may stabilize the 315 presence of hole-nesting bird species (Davies et al., 2009; Duckworth, 2014).

316 However, several authors argue that urban areas may be unstable in the long term.

317 Physical, social and vegetation changes associated with advances in urban technology, urban 318 decay, urban redevelopment and socioeconomic fluctuations may influence biotic communities

319 (Shaw et al., 2008; Luck et al., 2009; Hulme-Beaman et al., 2016). On the other hand, the use of 320 bird feeders by households may change considerably in the long term, affecting the occurrence 321 of bird species in backyards (Chamberlain et al., 2005). Finally, the colonization of cities by 322 predators, such as birds of prey or crows (Rutz 2008, Tomiałojć 2011), may promote directional 323 changes in bird composition by causing population declines in their prey species. 


\section{4. Temporal stabilization of bird composition}

\section{4.1. Diurnal scale}

327 Although there are many records of nocturnal activity by diurnal birds in urban areas (Sick and

328 Teixeira, 1981; Negro et al., 2000; Rejt, 2004; DeCandido and Allen, 2006; Mikula et al., 2013),

329 only a few studies related bird activity to environmental variables or urban attributes (Table 1).

330 All the studies were conducted in the Northern Hemisphere, mainly in Europe, and 10 out of 12

331 studies were performed in the 2010-2018 period. Six of eleven studies were focused on singing

332 behavior, and the most extensively studied species was the Blackbird (Turdus merula). In

333 general, most studies found more bird activity at night in areas with more artificial light. Other

334 factors such as day length and cloud cover may influence bird activity at night (Russ et al.,

335 2015). On the other hand, a couple of studies showed that anthropogenic noise can be the cause

336 of earlier dawn song in birds (Fuller et al. 2007, Arroyo-Solís et al. 2013).

337 The stabilization of bird composition between day and night can also be promoted by the 338 extinction of nocturnal species. For example, Weaving et al. (2011) found that two of the three

339 studied nocturnal species showed negative responses to urbanization in Melbourne, Australia.

340 However, Bosakowski and Smith (1997) found negative effects of urbanization only on the

341 Barred Owl (Strix varia), whereas the Great Horned Owl (Bubo virginianus) and the Eastern

342 Screech Owl (Otus asio) did not exhibit responses to urbanization.

4.2. Seasonal scale

345 Studies analyzing seasonal variation of bird composition along urbanization gradients are scarce and were conducted in the Southern and Northern Hemisphere, and generally performed during

347 the 2010-2018 period. All studies showed negative effects of urbanization on seasonality of bird 
348 composition (Table 2). Most of the studies compared seasonal dynamics between habitat types,

349 except for two studies that related seasonal changes of community composition to impervious

350 surface cover and other vegetation characteristics (Leveau et al., 2015; Leveau and Leveau,

351 2016). Many examples showed loss of migratory behaviour in bird species colonizing urban

352 environments: a) the Merlin (Falco columbarius, Warkentin et al., 1990); b) the European Robin

353 (Erithacus rubecula, Adriaensen and Dhondt, 1990); c) the Dark-eyed Junco (Junco hyemalis,

354 Yeh, 2004); d) the House Sparrow (Passer domesticus, Anderson, 2006); and e) the European

355 blackbird (Turdus merula, Partecke and Gwinner, 2007; Møller et al., 2014). However,

356 supplementary food during winter has been associated with northward winter migration of the

357 Eurasian Blackcap (Sylvia atricapilla) in Europe (Plummer et al. 2015).

358

359

\subsection{Interannual scale}

360

Most of the eight studies analyzed were conducted in the Northern Hemisphere, and during the 2010-2018 period (six out of eight studies). Five studies were long term ( $>5$ years). In general, studies showed that urbanization stabilized the interannual variation of community composition

363 (Table 3). However, two studies that spanned the longest term found null effects of urbanization 364 or opposite trends than expected (Barrett et al., 2008; Catterall et al., 2010). In particular,

365 Catterall et al. (2010) found population declines of urban-associated species, such as the House 366 Sparrow or European Starling (Sturnus vulgaris) in suburban habitats compared with bushland.

367 Most of studies related community composition stability to urban attributes, such as impervious 368 cover or human density.

\section{Possible mechanisms}


371 The role of stabilization of biotic and abiotic factors seems to vary at the different temporal

372 scales. At the diurnal scale, stabilization of abiotic conditions such as light seems to be the most

373 relevant, inducing nocturnal activity of birds. On the other hand, artificial light can increase food

374 availability for nocturnal birds, especially insectivores. However, in the case of species that feed

375 on human food waste or earthworms, such as Columba livia or Turdus sp., food resource does

376 not seem to be a limiting factor at night. Moreover, without artificial light, it is difficult that

377 diurnal species could find food. At the seasonal and interannual scales, the stabilization of biotic

378 factors seems to be the dominant determinant of bird composition stabilization. However, this

379 stabilization of biotic factors is usually mediated by the effect of abiotic factors, such as water or

380 the urban heat island phenomenon during winter.

\section{5. 1. Diurnal homogenization of bird composition}

382 Studies suggest that nocturnal activity is mainly regulated by artificial light, which alters

383 melatonin secretion (Dominoni et al., 2013a). Melatonin is a hormone related to the biological

384 rhythm in animals (Jones et al., 2015). Daylength may be a significant factor, as birds presented

385 the greatest night activity on shortest days (Russ et al., 2014; Dominoni and Partecke, 2015).

386 Meteorological factors such as temperature and cloud cover may influence the nocturnal activity

387 of birds (Russ et al. 2014; Dominoni et al. 2014). Bird density was positively related to the

388 degree of nocturnal activity, suggesting a role of intraspecific competition (Russ et al., 2015;

389 Dominoni et al., 2013b). Alternatively, a greater bird density may promote a greater probability

390 of appearance of nocturnal feeding (Figure 1). Finally, the importance of food availability at

391 night was suggested, but it was very little explored (Dominoni et al., 2014). However, other

392 authors postulated that birds may have lower energetic demands during winter and may delay the

393 start of foraging activity as a response to the urban heat island phenomenon (Ockendon et al. 
394 2009, Clewley et al. 2016).

395 5. 2. Seasonal homogenization of bird composition

396 The lower seasonal variation of bird communities in urban than in non-urban areas may be

397 related to the extinction of migratory species and to the lower seasonal variation of resident

398 species (Pennington et al. 2008, Jokimäki and Kaisanlahti-Jokimäki 2012b). Migratory species

399 arrive at a site to exploit surplus resources not used by year-round residents (MacArthur, 1959;

400 Hurlbert and Haskell 2003). If urban areas were characterized by a stabilization of resources, the

401 surplus provided to migratory species would be diminished (Figure 1). Nevertheless, urban areas

402 may be characterized by a low amount of food resources to migrants, especially those that feed

403 on insects (Faeth et al., 2005, Teglhøj 2017). Moreover, human disturbance such as pedestrian

404 and car traffic, and nest parasitism may be especially negative to migratory birds (Burger and

405 Gochfeld, 1991; Zhou and Chu, 2012; Rodewald and Shustack, 2008) (Figure 1). In seasonally

406 temperate areas, constant food availability to omnivorous and insectivorous species throughout

407 the year may stabilize their temporal variation relative to populations in rural or natural areas.

408 For instance, the African woolly-necked stork (Ciconia microscelis) were provided

409 supplementary food by humans year-round in KwaZulu-Natal (South Africa), and humans were

410 motivated by pleasure (Thabethe and Downs, 2018). Silvereyes (Zosterops lateralis) in Dunedin

411 (New Zealand) complemented their seasonal foraging on insects by using exotic and native trees

412 (Waite et al. 2013); the exotic English oak (Quercus robur) had the highest abundance of

413 arthropods. The advance of reproductive phenology in the Abert 's Towhee (Melozone aberti) in

414 Phoenix was related to predictability and limited change of food resources in urban areas (Davies

415 et al. 2016).

416 The increased stable presence of resident species may negatively affect migratory species 
417 by interspecific competition for food and nesting places (Figure 1). For example, House

418 sparrows may use aerial hawking of insects, depleting resources for migratory species that

419 exploit the same resources. House Sparrows and European Starlings nest in holes of buildings

420 and trees, the same nest substrates as those used by several migratory swallow and swift species

421 in the Neotropic, Neartic and Paleartic regions (Palomino and Carrascal, 2006; Leveau et al.,

422 2015; Chantler and Boesman 2018). Finally, supplementary feeding during winter may generate

423 a surplus of resources, favouring the arrival of winter migrants (Plummer et al. 2015), and

424 therefore promoting an opposite process to seasonal homogenization of bird communities.

425 On the other hand, quantity and quality of food, artificial light and the urban heat island

426 phenomenon may affect the physiology of bird individuals, altering their phenology by

427 lengthening the breeding season (Deviche and Davies 2014). A continental study across Europe

428 showed that several species had a longer singing period (as a proxy of the breeding season) in

429 urban than in rural areas (Møller et al. 2015). Moreover, this effect of urbanization was higher in 430 species that colonized cities long before other species and in the biggest cities, due to a target

431 effect and a lower risk of extinction (mechanism of island biogeography, Møller et al. 2015). It is

432 noteworthy that this longer breeding season in urban areas was also observed in migratory

433 species, despite the negative effects of urbanization on this group of species (see references

434 above).

435 5.3. Interannual homogenization of bird composition

436 Interannual composition stability in highly urbanized areas is probably driven by the high

437 densities that some species reach there, favoured by several factors such as a constant food

438 supply, habitat stability and a favourable microclimate during winter (Figure 1). A high

439 dominance of a few species, typically the House Sparrow and the Rock Dove, may diminish their 
440 extinction probabilities at local scales, at least in the short and mid-term (between 2 and 10

441 years). However, at longer temporal scales ( $>10$ years), biotic instabilities may occur due to

442 strong competitive interactions between species (DeAngelis and Waterhouse, 1987). Shochat et

443 al. (2010) showed that dominant bird species were highly efficient foragers that leave scarce

444 resources to subordinate species, probably leading to their exclusion in the long term. On the

445 other hand, bird community fluctuations are probably more governed by environmental

446 stochasticities in rural or natural than in urban areas, due to natural disturbances or climatic

447 fluctuations, which affect the persistence of rare species, leading to increased temporal variation

448 of bird composition (Collins, 2000; Sasaki and Lauenroth, 2011).

\section{6. Effects on the trophic dynamics of predators}

451 The dampening in biotic resources and bird species composition in urban areas may impact the

452 trophic dynamics of vertebrate predators, such as cats or raptors. For example, free-ranging cats 453 had less marked seasonal variations of diet composition in urban than in rural areas (Krauze-

454 Gryz et al., 2017). Urban Black vultures (Coragyps atratus) presented a uniform use of carrion

455 throughout the year, whereas rural vultures showed a fluctuation in diet composition from 456 arthropods to carrion (Ballejo and de Santis, 2013). Finally, the seasonal variation of diet 457 composition in the Tawny owl (Strix aluco) was lower in the city of Warsaw than in a nearby 458 forest, mainly due to predation on the resident House sparrow (Passer domesticus) (Goszczyński 459 et al., 1993).

460

462 In my opinion, spatial and temporal homogenization acts at different spatial scales and has 
463 different underlying processes. On the one hand, spatial homogenization is the increase of

464 taxonomic similarity between two or more biotas over a specified time interval (Olden and

465 Rooney, 2006). The main process is the extinction of native species and the colonization of

466 widespread species. On the other hand, temporal homogenization is the increase of taxonomic

467 similarity in a given biota over time. This phenomenon occurs at several temporal scales, as

468 mentioned above. Underlying processes are the extinction of migratory or disturbance-dependent 469 species and the colonization of new temporal niches (e.g., the night; Hut et al., 2012).

$470 \quad$ Are both processes simultaneous? The spatial homogenization of bird composition

471 promoted by urbanization seems to be scale-dependent. While at a global scale or when

472 comparing different biomes, there is a higher taxonomic similarity in the most urbanized areas

473 than in less urbanized and non-urban areas (Clergeau et al., 2001; Leveau et al., 2017a), at the

474 regional scale avifaunas of highly urbanized areas seem to be as heterogeneous as suburban

475 avifaunas (Leveau et al., 2017b). On the other hand, temporal homogenization of avifaunas can

476 be considered at different spatial scales, from the local to the global scale. For example, seasonal

477 stabilization of bird composition was detected at local scales in Argentina (Leveau et al., 2015;

478 Leveau and Leveau, 2016) and among different biomes in North America (La Sorte et al., 2014).

479 The nocturnal activity of Rock Doves in urban centres is a global phenomenon (Luniak, 2004;

480 Leveau unpublished data).

481

482 8. Conclusions and future directions

483 Published evidence suggests that urban areas dampen the natural cycles at several temporal

484 scales. The stabilization of biotic and abiotic factors, such as light, temperature, food and habitat

485 structure, are desynchronized from natural diurnal, seasonal and interannual cycles. These 
486 changes induced by urbanization are expected to influence the temporal dynamics of bird

487 composition. In fact, the reviewed literature showed that bird composition was temporally most

488 stable in the most urbanized areas, leading to a temporal homogenization of bird communities

489 (Fig. 1). As a result, urbanization promotes a decline of temporal beta diversity. However, the

490 studies analyzed only covered taxonomic diversity, whereas other facets of biodiversity, such as

491 functional or phylogenetic diversities, remain unexplored.

492

A possible consequence of resource and habitat stabilization is population growth and

493

494

495

496

497

498

499

500

501

502

503

504

505

506

507

508

range expansion of bird species adapted to urban conditions. For instance, a recent study showed that daily nest survival rates of Blackbirds increased with artificial light at night (Russ et al., 2017). On the other hand, clear examples of species with range expansions associated with urban conditions are hummingbirds; for example, the Anna's Hummingbird (Calypte anna), the Allen's Hummingbird (Selasphorus sasin sedentarius) and the White-throated Hummingbird (Leucochloris albicollis) have expanded their range sizes and are highly associated with residential areas, which provide supplementary food resources such as nectar, year-round flowering plants and nesting sites (Clark and Russel, 2012; Clark, 2017; Greig et al., 2017; Weller et al., 2017). Psitacidae species, such as the Rose-ringed parakeet (Psittacula krameri) and the Monk Parakeet (Myiopsitta monachus) in Europe and the Rainbow Lorikeet (Trichoglossus haematodus) in Australia, expanded their distributions associated with food and nesting resources provided in urban areas (Shukuroglou and McCarthy, 2006; Strubbe and Matthysen, 2009; Clergeau and Vergnes, 2011). Despite these findings, there are many research gaps that need to be filled.

Studies concerning the nocturnal activity of diurnal species were focused on the analysis of intervening factors and experimentation, but research was exhaustive only on the European 
509 Blackbird. It is noteworthy that other globally distributed species with nocturnal activity such as

510 the Rock Dove have still not been studied (Luniak, 2004). This is an interesting model species to 511 explore environmental conditions affecting nocturnal activity.

512 Although there are no studies that compare bird composition similarity between day and 513 night, in those studies reporting nocturnal activity of some diurnal species, I assumed that those 514 species also had diurnal activity that was not mentioned. In fact, several studies showed this 515 pattern (Byrkjedal et al., 2012; MacGregor-Fors et al., 2011; Russ et al. 2015). Therefore, in 516 those urbanized areas, species similarity between day and night is higher than in areas where 517 there is no nocturnal activity of typical diurnal birds. However, there is a need to formally 518 compare the similarity in composition between day and night along urbanization gradients.

519 Comparisons of seasonal and interannual compositional stability between urbanization

520 levels have been conducted for different countries (Table 1); however, studies that relate 521 compositional stability to temporal environmental variation are scarce. A recent study showed 522 that seasonal change of primary productivity was directly related to seasonal change of bird 523 composition (Leveau et al., 2018). In addition, experimental studies controlling or altering the 524 temporal availability of resources and their effect on bird composition stability are needed. A 525 relevant example is a work of Galbraith et al. (2015), in which supplementary food was 526 experimentally added in residential areas and removed after 18 months, promoting a higher 527 temporal variation of bird composition than in control sites where food availability was not 528 altered.

529 Given that wealthier householders may provide more resources for habitat management 530 and bird feeding, leading to a higher biodiversity (the so called luxury effect, Leong et al., 2018), 531 it is expected that this type of intervention may promote an increase in temporal stabilization in 
532 bird composition. These socioeconomic contrasts may act at different spatial scales, from the

533 local scale, comparing different residential areas within a city, to the global scale, comparing

534 cities of developed and developing countries, or arid versus tropical biomes (Leong et al., 2018).

535 The stabilizing role of urbanization in environmental conditions may be more or less

536 evident, depending on the geographical location of cities. For example, desert biomes are highly

537 variable according to interannual precipitations (Fang et al., 2001) and, therefore, irrigation in

538 residential areas may exert higher effects on the stability of bird composition than irrigation in

539 urban areas of forested biomes, which may have lower interannual fluctuations in precipitation.

540 As a result of higher environmental and population variability with time and habitat

541 succession, bird communities are expected to show more variability as the time of observations

542 of studies increases (Bengtsson et al., 1997). In part, our review resulted in patterns of

543 interannual variability opposed to those expected for those studies with more than 10 years of

544 observation period (Table 1). Therefore, studies conducted at longer temporal scales are needed

545 (see also Fidino and Magle, 2017). On the other hand, although bird composition may change

546 greatly between years, it is necessary to explore whether bird communities of urban areas

547 undergo directional changes through time (Collins, 2000; Collins et al., 2000).

548 An overlooked aspect of urban environments is the possible creation of rhythms in bird

549 communities as a response to massive movement of people between weekdays and weekends.

550 Car traffic may promote weekly cycles of pollutants, wind speed and noise, which may cause

551 changes in bird activity (Shutters and Balling, 2006; Leveau, 2008; Halfwerk et al., 2011). Along

552 a road near Madrid, Bautista et al. (2004) found changes in raptor composition between

553 weekdays and weekends. On the other hand, Fernández-Juricic et al. (2003) found that the

554 presence of pedestrians in urban parks of Madrid affected the abundance of House Sparrows. 
555 Lafferty (2001) found a marginal difference $(\mathrm{P}<0.10)$ of bird abundance between weekdays and

556 weekends in sandy beaches of California and a significant interaction between weekends and

557 seasons, suggesting that the effect of human density may depend on the period of the year and

558 bird phenology. Therefore, we may expect significant changes in bird composition between

559 weekdays and weekends in urban green spaces, because a massive number of people usually visit

560 them on weekends.

561 The dampening of temporal variation in bird composition may be another aspect of the

562 so-called extinction of experience (Pyle, 1978; Miller, 2005), i.e., humans are disconnected from

563 natural cycles. It has been reported that most people liked the change of seasons (Jauhiainen and

564 Mönkkönen, 2005; Soga et al., 2016), and Palang et al. (2005) recommended to pay more

565 attention to seasonality in landscape planning. Moreover, although little explored, the seasonal

566 variation of vegetation and animal activity may have an aesthetic value and support ecosystem

567 services (Dronova, 2017). For instance, Graves et al. (2018) found that the type of cultural

568 ecosystem services, such as birdwatching, varied spatio-temporally along an urbanization

569 gradient, because resident and migrant species had different responses to land covers. From a

570 point of view of urban design, it is a paradox that urban habitats that we ignore, such as vacant

571 lots, are more related to the particular natural processes of the region in which the city is located

572 than those places designed in a formal way with particular proportions of lawn, shrubs and trees

573 (Hough, 1994; Kwok, 2018). Therefore, a crucial step to restoring nature in cities is to pay

574 attention to the natural cycles that are characteristic of the surroundings of cities.

575 Recently, a collaborative project that encompassed six metropolitan areas of varied

576 climatic regions of the USA aimed to elucidate the ecological homogenization of urban areas

577 compared to natural areas, showing convergences of soil moisture, amount of organic matter and 
578 microclimate among residential areas (Groffman et al., 2014; Hall et al., 2016). In my opinion, a

579 step forward is to analyze how these ecosystem properties are stabilized over time, and how this 580 affects the temporal persistence of bird species.

581

\section{Acknowledgments}

583 I thank the Editor, Piotr Tryjanowski, Adrian Davis, Jukka Jokimäki, Jorgelina Brasca and two 584 anonymous reviewers for valuable comments that improved the manuscript.

585

586

\section{References}

587 Adriaensen, F., \& Dhondt, A. A. (1990). Population dynamics and partial migration of the 588 European robin (Erithacus rubecula) in different habitats. The Journal of Animal Ecology, 10775891090.

590 Argañaraz, J. P., Pizarro, G. G., Zak, M., Landi, M. A., \& Bellis, L. M. (2015). Human and 591 biophysical drivers of fires in Semiarid Chaco mountains of Central Argentina. Science of the 592 Total Environment, 520, 1-12.

593 Anderson, T. R. (2006). Biology of the ubiquitous house sparrow: from genes to populations. 594 Oxford University Press.

595 Arizmendi, M., López-Saut, E., Monterrubio-Solís, C., Juárez, L., Flores-Moreno, I., \&

596 Rodríguez-Flores, C. (2008). Efecto de la presencia de bebederos artificiales sobre la diversidad 597 y abundancia de los colibríes y el éxito reproductivo de dos especies de plantas en un parque 598 suburbano de la ciudad de México. Ornitología Neotropical, 19, 491-500. 
599 Arroyo-Solís, A., Castillo, J. M., Figueroa, E., López-Sánchez, J. L., \& Slabbekoorn, H. (2013).

600 Experimental evidence for an impact of anthropogenic noise on dawn chorus timing in urban 601 birds. Journal of Avian Biology, 44(3), 288-296.

602 Ballejo, F., \& de Santis, L. J. (2013). Dieta estacional del Jote Cabeza Negra (Coragyps atratus) 603 en un área rural y una urbana en el noroeste patagónico. El hornero, 28(1), 07-14.

604 Bang, C., Sabo, J. L., \& Faeth, S. H. (2010). Reduced wind speed improves plant growth in a 605 desert city. PLoS One, 5(6), e11061.

606 Bang, C., Faeth, S. H., \& Sabo, J. L. (2012). Control of arthropod abundance, richness, and 607 composition in a heterogeneous desert city. Ecological Monographs, 82(1), 85-100.

608 Banville, M. J., Bateman, H. L., Earl, S. R., \& Warren, P. S. (2017). Decadal declines in bird 609 abundance and diversity in urban riparian zones. Landscape and Urban Planning, 159, 48-61.

610 Barrett, K., Romagosa, C. M., \& Williams, M. I. (2008). Long-term bird assemblage trends in 611 areas of high and low human population density. International Journal of Ecology

612 Baruah, S., \& Dutta, P. (2013). Seasonal prevalence of Aedes aegypti in urban and industrial 613 areas of Dibrugarh district, Assam. Trop Biomed, 30(434), 43.

614 Bautista, L. M., García, J. T., Calmaestra, R. G., Palacín, C., Martín, C. A., Morales, M. B., 615 Bonal, R., \& Viñuela, J. (2004). Effect of weekend road traffic on the use of space by 616 raptors. Conservation Biology, 18(3), 726-732.

617 Belaire, J. A., Westphal, L. M., Whelan, C. J., \& Minor, E. S. (2015). Urban residents’ 618 perceptions of birds in the neighborhood: biodiversity, cultural ecosystem services, and 619 disservices. The Condor, 117(2), 192-202. 
620 Bengtsson, J., Baillie, S. R., Lawton, J. (1997). Community variability increases with time. 621 Oikos 78, 249-256.

622 Beninde, J., Veith, M., \& Hochkirch, A. (2015). Biodiversity in cities needs space: a

623 meta-analysis of factors determining intra-urban biodiversity variation. Ecology letters, 18(6), $624 \quad 581-592$.

625 Bennie, J., Duffy, J. P., Davies, T. W., Correa-Cano, M. E., \& Gaston, K. J. (2015). Global 626 trends in exposure to light pollution in natural terrestrial ecosystems. Remote Sensing, 7(3), $627 \quad 2715-2730$.

628 Blair, R. B. (1996). Land use and avian species diversity along an urban gradient. Ecological 629 applications, 6(2), 506-519.

630 Böhm, F., Brückner, J., Eichhorn, D., Geiger, R., Johl, B., Kahl, S., Kleudgen, I., K[ohler, K., 631 Kreifelys, V., Metchske, K., Meyer, M., Richter, A. C., Schulze, B., Stecker, R.M., Steinhoff, P. 632 O. M., Winter, M., \& Meyer, M. (2016). Cloud cover but not artificial light pollution affects the 633 morning activity of Wood Pigeons. Ornis Fennica, 93(4), 246-252.

634 Bosakowski, T., \& Smith, D. G. (1997). Distribution and species richness of a forest raptor 635 community in relation to urbanization. Journal of Raptor Research, 31, 26-33.

636 Branoff, B. (2018). Changes in mangrove tree mortality, forest canopy, and aboveground 637 biomass accumulation rates following the 2017 hurricane season in Puerto Rico and the role of 638 urbanization. bioRxiv, 425140.

639 Burger, J., \& Gochfeld, M. (1991). Human distance and birds: tolerance and response distances 640 of resident and migrant species in India. Environmental Conservation 18,158-165 
641 Buyantuyev, A., \& Wu, J. (2012). Urbanization diversifies land surface phenology in arid 642 environments: interactions among vegetation, climatic variation, and land use pattern in the 643 Phoenix metropolitan region, USA. Landscape and Urban Planning, 105(1), 149-159.

644 Byrkjedal, I., Lislevand, T., \& Vogler, S. (2012). Do passerine birds utilise artificial light to 645 prolong their diurnal activity during winter at northern latitudes?. Ornis Norvegica, 35, 37-42.

646 Carbajo, A. E., Gomez, S. M., Curto, S. I., \& Schweigmann, N. J. (2004). Variación espacio647 temporal del riesgo de transmisión de dengue en la Ciudad de Buenos Aires. Medicina (Buenos 648 Aires), 64(3), 231-234.

649 Catterall, C. P., Cousin, J. A., Piper, S., \& Johnson, G. (2010). Long-term dynamics of bird 650 diversity in forest and suburb: decay, turnover or homogenization?. Diversity and 651 Distributions, 16(4), 559-570.

652 Caula, S., Marty, P., \& Martin, J. L. (2008). Seasonal variation in species composition of an 653 urban bird community in Mediterranean France. Landscape and Urban Planning, 87(1), 1-9.

654 Chace, J. F., \& Walsh, J. J. (2006). Urban effects on native avifauna: a review. Landscape and 655 urban planning, 74(1), 46-69.

656 Chamberlain, D. E., Vickery, J. A., Glue, D. E., Robinson, R. A., Conway, G. J., Woodburn, R. 657 J., \& Cannon, A. R. (2005). Annual and seasonal trends in the use of garden feeders by birds in 658 winter. Ibis, 147(3), 563-575.

659 Chang, C. T., Lin, T. C., Wang, S. F., \& Vadeboncoeur, M. A. (2011). Assessing growing season 660 beginning and end dates and their relation to climate in Taiwan using satellite data. International 661 Journal of Remote Sensing, 32(18), 5035-5058. 
662 Chantler, P. \& Boesman, P. (2018). Chimney Swift (Chaetura pelagica). In: del Hoyo, J., Elliott, 663 A., Sargatal, J., Christie, D.A. \& de Juana, E. (eds.). Handbook of the Birds of the World Alive. 664 Lynx Edicions, Barcelona. (retrieved from https://www.hbw.com/node/55310 on 19 July 2018).

665 Ciach, M., \& Fröhlich, A. (2016). Habitat type, food resources, noise and light pollution explain 666 the species composition, abundance, and stability of a winter bird assemblage in an urban 667 environment. Urban Ecosystems, 1-13.

668 Cinzano, P., Falchi, F., \& Elvidge, C. D. (2001). The first world atlas of the artificial night sky 669 brightness. Monthly Notices of the Royal Astronomical Society, 328(3), 689-707.

670 Comber, A., \& Brunsdon, C. (2015). A spatial analysis of plant phenophase changes and the 671 impact of increases in urban land use. International Journal of Climatology, 35(6), 972-980.

672 Clark, C. J. (2017). eBird records show substantial growth of the Allen's Hummingbird 673 (Selasphorus sasin sedentarius) population in urban Southern California. The Condor, 119(1), $674 \quad 122-130$.

675 Clark, C. J., and S. M. Russell (2012). Anna’s Hummingbird (Calypte anna). In Birds of North 676 America Online (P. G. Rodewald, Editor). Cornell Lab of Ornithology, Ithaca, NY, USA.

677 Clergeau, P., \& Vergnes, A. (2011). Bird feeders may sustain feral Rose-ringed parakeets 678 Psittacula krameri in temperate Europe. Wildlife Biology, 17(3), 248-252.

679 Clergeau, P., Jokimäki, J., \& Savard, J. P. L. (2001). Are urban bird communities influenced by 680 the bird diversity of adjacent landscapes?. Journal of applied ecology, 38(5), 1122-1134. 
681 Clewley, G. D., Plummer, K. E., Robinson, R. A., Simm, C. H., \& Toms, M. P. (2016). The 682 effect of artificial lighting on the arrival time of birds using garden feeding stations in winter: A 683 missed opportunity?. Urban ecosystems, 19(2), 535-546.

684 Coetzee, B. W., \& Chown, S. L. (2016). Land-use change promotes avian diversity at the 685 expense of species with unique traits. Ecology and Evolution, 6(21), 7610-7622.

686 Collins, S. L. (2000). Disturbance frequency and community stability in native tallgrass 687 prairie. The American Naturalist, 155(3), 311-325.

688 Collins, S. L., Micheli, F., \& Hartt, L. (2000). A method to determine rates and patterns of 689 variability in ecological communities. Oikos, 91(2), 285-293.

690 Coops, N. C., Wulder, M. A., \& Iwanicka, D. (2009). Exploring the relative importance of 691 satellite-derived descriptors of production, topography and land cover for predicting breeding 692 bird species richness over Ontario, Canada. Remote Sensing of Environment, 113(3), 668-679.

693 Corlett, R. T. (2005). Interactions between birds, fruit bats and exotic plants in urban Hong 694 Kong, South China. Urban Ecosystems, 8(3), 275-283.

695 Da Silva, A., \& Kempenaers, B. (2017). Singing from North to South: Latitudinal variation in 696 timing of dawn singing under natural and artificial light conditions. Journal of Animal 697 Ecology, 86(6), 1286-1297.

698 Dalby, L., McGill, B. J., Fox, A. D., \& Svenning, J. C. (2014). Seasonality drives global-scale 699 diversity patterns in waterfowl (Anseriformes) via temporal niche exploitation. Global Ecology 700 and Biogeography, 23(5), 550-562. 
701 Davies, S., Lane, S., Meddle, S. L., Tsutsui, K., \& Deviche, P. (2016). The ecological and

702 physiological bases of variation in the phenology of gonad growth in an urban and desert

703 songbird. General and comparative endocrinology, 230, 17-25.

704 Davies, T. W., Bennie, J., \& Gaston, K. J. (2012). Street lighting changes the composition of 705 invertebrate communities. Biology letters, rsbl20120216.

706 Davies, Z. G., Fuller, R. A., Loram, A., Irvine, K. N., Sims, V., \& Gaston, K. J. (2009). A

707 national scale inventory of resource provision for biodiversity within domestic

708 gardens. Biological Conservation, 142(4), 761-771.

709 Davies, Z. G., Fuller, R. A., Dallimer, M., Loram, A., \& Gaston, K. J. (2012). Household factors

710 influencing participation in bird feeding activity: a national scale analysis. PloS one, 7(6),

711 e39692.

712 Davis, A., Major, R. E., \& Taylor, C. E. (2015). The association between nectar availability and 713 nectarivore density in urban and natural environments. Urban Ecosystems, 18(2), 503-515.

714 Davis, A., Major, R. E., \& Taylor, C. E. (2016). Do trees flower longer in the city? A

715 comparison of flowering eucalyptus trees in streets, remnants and continuous forest and their

716 association with nectarivorous birds. Urban Ecosystems, 19(2), 735-747.

717 DeAngelis, D. L., \& Waterhouse, J. C. (1987). Equilibrium and nonequilibrium concepts in 718 ecological models. Ecological monographs, 57(1), 1-21.

719 DeCandido, R., \& Allen, D. (2006). Nocturnal hunting by peregrine falcons at the empire state 720 building, New York City. Wilson Journal of Ornithology, 118(1), 53-58. 
721 Deviche, P., \& Davies, S. (2014). Reproductive phenology of urban birds: Environmental cues 722 and mechanisms. In: Gil D, Brumm H (eds) Avian urban ecology: behavioural andphysiological 723 adaptations. Oxford University Press, Ox -ford, p 98-115

724 Dominoni, D. M., Goymann, W., Helm, B., \& Partecke, J. (2013a). Urban-like night illumination 725 reduces melatonin release in European blackbirds (Turdus merula): implications of city life for 726 biological time-keeping of songbirds. Frontiers in Zoology, 10(1), 60.

727 Dominoni, D. M., Helm, B., Lehmann, M., Dowse, H. B., \& Partecke, J. (2013b). Clocks for the 728 city: circadian differences between forest and city songbirds. Proceedings of the Royal Society of 729 London B: Biological Sciences, 280(1763), 20130593.

730 Dominoni, D. M., Carmona-Wagner, E. O., Hofmann, M., Kranstauber, B., \& Partecke, J.

731 (2014). Individual-based measurements of light intensity provide new insights into the effects of 732 artificial light at night on daily rhythms of urban-dwelling songbirds. Journal of Animal 733 Ecology, 83(3), 681-692.

734 Dominoni, D. M., \& Partecke, J. (2015). Does light pollution alter daylength? A test using light 735 loggers on free-ranging European blackbirds (Turdus merula). Phil. Trans. R. Soc. B, 370(1667), 73620140118.

737 Dronova, I. (2017). Environmental heterogeneity as a bridge between ecosystem service and 738 visual quality objectives in management, planning and design. Landscape and Urban 739 Planning, 163, 90-106. 
740 Duckworth, R. A. (2014). Human-induced changes in the dynamics of species coexistence: an

741 example with two sister species. Avian Urban Ecology: Behavioural and Physiological

742 Adaptations, 181.

743 Eisenbeis, G., Hänel, A., (2009). Light pollution and the impact of artificial night lighting on

744 insects. published in : McDonnell, M. J.;, Hahs, A. H., Breuste, J. H.: Ecology of Cities and

745 Towns, Cambridge University Press, Cambridge 2009, p. 243-263

746 Faeth, S. H., Bang, C., \& Saari, S. (2011). Urban biodiversity: patterns and mechanisms. Annals 747 of the New York Academy of Sciences, 1223(1), 69-81.

748 Faeth, S. H., Warren, P. S., Shochat, E., \& Marussich, W. A. (2005). Trophic dynamics in urban 749 communities. Bioscience, 55(5), 399-407.

750 Fang, J., Piao, S., Tang, Z., Peng, C., \& Ji, W. (2001). Interannual variability in net primary 751 production and precipitation. Science, 293(5536), 1723-1723.

752 Farnworth, B., Innes, J., Kelly, C., Littler, R., \& Waas, J. R. (2018). Photons and foraging:

753 Artificial light at night generates avoidance behaviour in male, but not female, New Zealand 754 weta. Environmental pollution, 236, 82-90.

755 Fernández-Juricic, E., Sallent, A., Sanz, R., \& RodrÍguez-Prieto, I. (2003). Testing the risk756 disturbance hypothesis in a fragmented landscape: nonlinear responses of house sparrows to 757 humans. The Condor, 105(2), 316-326.

758 ffrench-Constant, R. H., Somers-Yeates, R., Bennie, J., Economou, T., Hodgson, D., Spalding, 759 A., McGregor, P. K. (2016). Light pollution is associated with earlier tree budburst across the 760 United Kingdom. Proc. R. Soc. B 283: 20160813. 
761 Fidino, M., \& Magle, S. B. (2017). Trends in long-term urban bird research. In Ecology and

762 Conservation of Birds in Urban Environments (pp. 161-184). Springer, Cham.

763 Fuller, R. A., Warren, P. H., \& Gaston, K. J. (2007). Daytime noise predicts nocturnal singing in 764 urban robins. Biology letters, 3(4), 368-370.

765 Fuller, R. A., Warren, P. H., Armsworth, P. R., Barbosa, O., \& Gaston, K. J. (2008). Garden bird 766 feeding predicts the structure of urban avian assemblages. Diversity and Distributions, 14(1), $767 \quad 131-137$.

768 Galbraith, J. A., Beggs, J. R., Jones, D. N., \& Stanley, M. C. (2015). Supplementary feeding 769 restructures urban bird communities. Proceedings of the National Academy of Sciences, 112(20), 770 E2648-E2657.

771 Gaston, K. J., Fuller, R. A., Loram, A., MacDonald, C., Power, S., \& Dempsey, N. (2007).

772 Urban domestic gardens (XI): variation in urban wildlife gardening in the United

773 Kingdom. Biodiversity and conservation, 16(11), 3227-3238.

774 Gil, D., \& Brumm, H. (Eds.). (2014). Avian urban ecology. Oxford University Press, Oxford

775 Gliwicz, J., Goszczyński, J., \& Luniak, M. (1994). Characteristic features of animal populations

776 under synurbanization-the case of the blackbird and of the striped field mouse. Memorabilia

777 Zoologica, 49, 237-244.

778 González-García, A., \& Sal, A. G. (2008). Private urban greenspaces or “patios” as a key 779 element in the urban ecology of tropical central America. Human Ecology, 36(2), 291. 
780 Gorton, A. J., Moeller, D. A., \& Tiffin, P. (2018). Little plant, big city: a test of adaptation to

781 urban environments in common ragweed (Ambrosia artemisiifolia). Proc. R. Soc. B, 285(1881),

78220180968.

783 Goszczyński, J., Jabłoński, P. G., Lesiński, G., \& Romanowski, J. (1993). Variation in diet of

784 Tawny Owl Strix aluco L. along an urbanization gradient. Acta ornithologica, 27(2), 113-123.

785 Graves, R. A., Pearson, S. M., \& Turner, M. G. (2018). Effects of bird community dynamics on 786 the seasonal distribution of cultural ecosystem services. Ambio, 1-13.

787 Gray, E. R., \& van Heezik, Y. (2016). Exotic trees can sustain native birds in urban

788 woodlands. Urban Ecosystems, 19(1), 315-329.

789 Greig, E. I., Wood, E. M., \& Bonter, D. N. (2017). Winter range expansion of a hummingbird is 790 associated with urbanization and supplementary feeding. Proc. R. Soc. B

791 Grimm, N. B., Faeth, S. H., Golubiewski, N. E., Redman, C. L., Wu, J., Bai, X., \& Briggs, J. M. 792 (2008). Global change and the ecology of cities. Science, 319(5864), 756-760.

793 Groffman, P. M., Cavender-Bares, J., Bettez, N. D., Grove, J. M., Hall, S. J., Heffernan, J. B., 794 Hobbie, S. B., Larson, K.L., Morse J. L., Neill, C., nelson, K., O’Neill-Dunne, J., Ogden, L., 795 Pataki, D. N., Polsky, C., Chowdury, R. R., \& Steele, M. K. (2014) Ecological homogenization 796 of urban USA. Frontiers in Ecology and the Environt 12, 74-81

797 Halfwerk, W., Holleman, L. J., Lessells, C. K., \& Slabbekoorn, H. (2011). Negative impact of 798 traffic noise on avian reproductive success. Journal of Applied Ecology, 48(1), 210-219. 
799 Hale, J. D., Davies, G., Fairbrass, A. J., Matthews, T. J., Rogers, C. D., \& Sadler, J. P. (2013).

800 Mapping lightscapes: spatial patterning of artificial lighting in an urban landscape. PloS

801 one, 8(5), e61460.

802 Hall, S. J., Learned, J, Ruddell, B., Larson, K. L., Cavender-Bares, J., Bettez, N., Groffman, P.

803 M., Grove, J. M., Heffernan J. B. S. E. HobbieJ. L. MorseC. NeillK. C. NelsonJ. P. M. O’Neil-

804 Dunne, L., Ogden, D. E., Pataki, W. D., Pearse C., Polsky R., Roy Chowdhury, M. K., Steele, T.

805 L., \& E. Trammell. (2016) Convergence of microclimate in residential landscapes across diverse

806 cities in the United States. Landscape Ecology 31, 101-117.

807 Herrera, C. M. (1978). On the breeding distribution pattern of European migrant birds:

808 MacArthur's theme reexamined. The Auk 95, 496-509.

809 Hiscocks, P. D., \& Gudmundsson, S. (2010). The contribution of street lighting to light

810 pollution. Journal of the Royal Astronomical Society of Canada, 104, 190.

811 Hollis, G. E. (1975). The effect of urbanization on floods of different recurrence interval. Water

812 Resources Research, 11(3), 431-435.

813 Hooper, D. U., Chapin, F. S., Ewel, J. J., Hector, A., Inchausti, P., Lavorel, S., J. H. Lawton, D.

814 M. Lodge, M. Loreau, S. Naeem, B. Schmid, H. Setälä, A. J. Symstad, J. Vandermeer ,\&

815 Schmid, B. (2005). Effects of biodiversity on ecosystem functioning: a consensus of current

816 knowledge. Ecological Monographs, 75(1), 3-35.

817 Hough, M. (1994) Design with city nature: an overview of some issues. In The ecological city:

818 preserving and restoring urban biodiversity, R. H. Platt, R. A. Rowntree, P C. Muick (Eds.), The

819 University of Massachusetts Press, Amherst 
820 Huang, J., Lu, X. X., \& Sellers, J. M. (2007). A global comparative analysis of urban form:

821 Applying spatial metrics and remote sensing. Landscape and urban planning, 82(4), 184-197.

822 Hulme-Beaman, A., Dobney, K., Cucchi, T., \& Searle, J. B. (2016). An ecological and

823 evolutionary framework for commensalism in anthropogenic environments. Trends in ecology \&

824 evolution, 31(8), 633-645.

825 Hurlbert, A. H., \& Haskell, J. P. (2003) The effect of energy and seasonality on avian species

826 richness and community composition. American Naturalist 161, 83-97

827 Hut, R. A., Kronfeld-Schor, N., van der Vinne, V., \& De la Iglesia, H. (2012). In search of a

828 temporal niche: environmental factors. In Progress in brain research (Vol. 199, pp. 281-304).

829 Elsevier.

830 Imhoff, M. L., Tucker, C. J., Lawrence, W. T., \& Stutzer, D. C. (2000). The use of multisource

831 satellite and geospatial data to study the effect of urbanization on primary productivity in the

832 United States. IEEE Transactions on Geoscience and Remote Sensing, 38(6), 2549-2556.

833 Jacobson, C. R. (2011). Identification and quantification of the hydrological impacts of

834 imperviousness in urban catchments: A review. Journal of Environmental Management, 92(6), $835 \quad 1438-1448$.

836 Jaksić, F. M. (1982). Inadequacy of activity time as a niche difference: the case of diurnal and 837 nocturnal raptors. Oecologia, 52(2), 171-175.

838 Jauhiainen, J. S., \& Mönkkönen, M. (2005). Seasonality: Nature, people's preferences and urban 839 planning in Oulunsalo, Finland. Landscape Research, 30(2), 273-281. 
840 Jeong, J. H., Ho, C. H., Linderholm, H. W., Jeong, S. J., Chen, D., \& Choi, Y. S. (2011). Impact

841 of urban warming on earlier spring flowering in Korea. International Journal of

842 Climatology, 31(10), 1488-1497.

843 Jokimäki, J., \& Kaisanlahti-Jokimäki, M. L. (2012a). The role of residential habitat type on the

844 temporal variation of wintering bird assemblages in northern Finland. Ornis Fennica, 89(1), 20.

845 Jokimäki, J., \& Kaisanlahti-Jokimäki, M. L. (2012b). Residential areas support overwintering

846 possibilities of most bird species. Annales Zoologici Fennici, 49, 240-256).

847 Jones, D. N., \& James Reynolds, S. (2008). Feeding birds in our towns and cities: a global

848 research opportunity. Journal of avian biology, 39(3), 265-271.

849 Jones, T. M., Durrant, J., Michaelides, E. B., \& Green, M. P. (2015). Melatonin: a possible link

850 between the presence of artificial light at night and reductions in biological fitness. Phil. Trans.

851 R. Soc. B, 370(1667), 20140122.

852 Katz, Y., \& Levin, N. (2016). Quantifying urban light pollution-A comparison between field

853 measurements and EROS-B imagery. Remote sensing of environment, 177, 65-77.

854 Kempenaers, B., Borgström, P., Loës, P., Schlicht, E., \& Valcu, M. (2010). Artificial night

855 lighting affects dawn song, extra-pair siring success, and lay date in songbirds. Current

856 Biology, 20(19), 1735-1739.

857 Konrad, C. P. (2003). Effects of urban development on floods. U.S. Geological Survey-Water

858 Resources

859 Krauze-Gryz, D., Żmihorski, M., \& Gryz, J. (2017). Annual variation in prey composition of

860 domestic cats in rural and urban environment. Urban Ecosystems, 20(4), 945-952. 
861 Kronfeld-Schor, N., \& Dayan, T. (2003). Partitioning of time as an ecological resource. Annual

862 Review of Ecology, Evolution, and Systematics, 34(1), 153-181.

863 Kuechly, H. U., Kyba, C. C., Ruhtz, T., Lindemann, C., Wolter, C., Fischer, J., \& Hölker, F.

864 (2012). Aerial survey and spatial analysis of sources of light pollution in Berlin,

865 Germany. Remote Sensing of Environment, 126, 39-50.

866 Kwok, R. (2018). Accidental urban oases. Proceedings of the National Academy of

867 Sciences, 115(19), 4800-4804.

868 Kyba, C. C. M., Ruhtz, T., Fischer, J., \& Hölker, F. (2012). Red is the new black: how the colour 869 of urban skyglow varies with cloud cover. Monthly Notices of the Royal Astronomical 870 Society, 425(1), 701-708.

871 La, V. T. (2012). Diurnal and nocturnal birds vocalize at night: a review. The Condor, 114(2), $872 \quad 245-257$.

873 Lafferty, K. D. (2001). Birds at a Southern California beach: seasonality, habitat use and 874 disturbance by human activity. Biodiversity \& Conservation, 10(11), 1949-1962.

875 La Sorte, F. A., Tingley, M. W., \& Hurlbert, A. H. (2014). The role of urban and agricultural 876 areas during avian migration: an assessment of within-year temporal turnover. Global ecology 877 and biogeography, 23(11), 1225-1234.

878 Lazzarini, M., Molini, A., Marpu, P. R., Ouarda, T. B., \& Ghedira, H. (2015). Urban climate 879 modifications in hot desert cities: The role of land cover, local climate, and 880 seasonality. Geophysical Research Letters, 42(22), 9980-9989. 
881 Leong, M., \& Roderick, G. K. (2015). Remote sensing captures varying temporal patterns of

882 vegetation between human-altered and natural landscapes. PeerJ, 3, e1141.

883 Leong, M., Dunn, R. R., \& Trautwein, M. D. (2018). Biodiversity and socioeconomics in the 884 city: a review of the luxury effect. Biology letters, 14(5), 20180082.

885 Lepczyk, C. A., Mertig, A. G., \& Liu, J. (2004). Assessing landowner activities related to birds 886 across rural-to-urban landscapes. Environmental Management, 33(1), 110-125.

887 Lepczyk, C. A., La Sorte, F. A., Aronson, M. F., Goddard, M. A., MacGregor-Fors, I., Nilon, C. 888 H., \& Warren, P. S. (2017). Global patterns and drivers of urban bird diversity. In Ecology and 889 conservation of birds in urban environments (pp. 13-33). Springer, Cham.

890 Leston, L. F., \& Rodewald, A. D. (2006). Are urban forests ecological traps for understory birds? 891 An examination using Northern cardinals. Biological Conservation, 131(4), 566-574.

892 Leveau, L. M. (2008). Dynamics of nectarivory in the house sparrow in an urban 893 environment. Ornitol Neotrop, 19, 275-281.

894 Leveau, L. M., \& Leveau, C. M. (2011). Nectarivorous feeding by the Bay-winged Cowbird 895 (Agelaioides badius). Studies on neotropical fauna and environment, 46(3), 173-175.

896 Leveau, L. M., \& Leveau, C. M. (2012). The role of urbanization and seasonality on the temporal 897 variability of bird communities. Landscape and urban planning, 106(3), 271-276.

898 Leveau, L. M., \& Leveau, C. M. (2016). Does urbanization affect the seasonal dynamics of bird 899 communities in urban parks?. Urban Ecosystems, 19(2), 631-647. 
900 Leveau, L. M., Isla, F. I., \& Bellocq, M. I. (2015). Urbanization and the temporal

901 homogenization of bird communities: a case study in central Argentina. Urban

902 Ecosystems, 18(4), 1461-1476.

903 Leveau, L. M., Leveau, C. M., Villegas, M., Cursach, J. A., \& Suazo, C. G. (2017a). Bird

904 communities along urbanization gradients: a comparative analysis among three Neotropical 905 cities. Ornitología Neotropical, 28, 77-87.

906 Leveau, L. M., Jokimäki, J., \& Kaisanlahti-Jokimäki, M. L. (2017b). Scale dependence of biotic

907 homogenisation by urbanisation: a comparison of urban bird communities between central 908 Argentina and northern Finland. European Journal of Ecology, 3(2), 1-18.

909 Leveau, L. M., Isla, F. I., \& Bellocq, M. I. (2018). Predicting the seasonal dynamics of bird 910 communities along an urban-rural gradient using NDVI. Landscape and Urban Planning, 177, $911 \quad 103-113$.

912 Lim, H. S., Ngarambe, J., Kim, J. T., \& Kim, G. (2018). The Reality of Light Pollution: A Field

913 Survey for the Determination of Lighting Environmental Management Zones in South

914 Korea. Sustainability, 10(2), 374.

915 Liu, C., Glitzenstein, J. S., Harcombe, P. A., \& Knox, R. G. (1997). Tornado and fire effects on 916 tree species composition in a savanna in the Big Thicket National Preserve, southeast Texas, 917 USA. Forest ecology and management, 91(2-3), 279-289.

918 Longcore, T., \& Rich, C. (2004). Ecological light pollution. Frontiers in Ecology and the 919 Environment, 2(4), 191-198. 
920 Longcore, T., Aldern, H. L., Eggers, J. F., Flores, S., Franco, L., Hirshfield-Yamanishi, E.,

921 Petrinec, L. N., Yan, W. A., \& Barroso, A. M. (2015). Tuning the white light spectrum of light

922 emitting diode lamps to reduce attraction of nocturnal arthropods. Phil. Trans. R. Soc.

$923 B, 370(1667), 20140125$.

924 Loram, A., Warren, P., Thompson, K., \& Gaston, K. (2011). Urban domestic gardens: the effects

925 of human interventions on garden composition. Environmental Management, 48(4), 808.

926 Luck, G. W., Smallbone, L. T., \& O’Brien, R. (2009). Socio-economics and vegetation change in

927 urban ecosystems: patterns in space and time. Ecosystems, 12(4), 604.

928 Luginbuhl, C. B., Lockwood, G. W., Davis, D. R., Pick, K., \& Selders, J. (2009). From the 929 ground up I: light pollution sources in Flagstaff, Arizona. Publications of the Astronomical 930 Society of the Pacific, 121(876), 185.

931 Luniak, M. (2004). Synurbization-adaptation of animal wildlife to urban development. In Proc. 932 4th Int. Symposium Urban Wildl. Conserv. Tucson (pp. 50-55).

933 Luo, Z., Sun, O. J., Ge, Q., Xu, W., \& Zheng, J. (2007). Phenological responses of plants to 934 climate change in an urban environment. Ecological Research, 22(3), 507-514.

935 Lyytimäki, J., Petersen, L. K., Normander, B., \& Bezák, P. (2008). Nature as a nuisance?

936 Ecosystem services and disservices to urban lifestyle. Environmental sciences, 5(3), 161-172.

937 Ma, T. (2018). An Estimate of the Pixel-Level Connection between Visible Infrared Imaging 938 Radiometer Suite Day/Night Band (VIIRS DNB) Nighttime Lights and Land Features across 939 China. Remote Sensing, 10(5), 723. 
940 MacArthur RH (1959) On the breeding distribution pattern of North American migrant birds.

941 Auk 76:318-325.

942 MacGregor-Fors, I., Blanco-García, A., Chávez-Zichinelli, C., Maya-Elisararrás, E., Mirón, L.,

943 Morales-Pérez, L., Perdomo, H., \& Schondube, J. E. (2011). Relación entre la presencia de luz

944 artificial nocturna y la actividad del mosquero cardinal (Pyrocephalus rubinus). El Canto del

945 Centzontle, 2, 64-71.

946 Marateo, G., Grilli, P., Bouzas, N., Jensen, R., Ferretti, V., Juárez, M., \& Soave, G. (2013). Uso

947 de hábitat por aves en rellenos sanitarios del noreste de la provincia de Buenos Aires,

948 Argentina. Ecología austral, 23(3), 202-208.

949 Martin, J., French, K., \& Major, R. (2010). Population and breeding trends of an urban coloniser:

950 the Australian white ibis. Wildlife Research, 37(3), 230-239.

951 Massetti, L. (2018). Assessing the impact of street lighting on Platanus x acerifolia

952 phenology. Urban Forestry \& Urban Greening.

953 McIntyre, N. E., Rango, J., Fagan, W. F., \& Faeth, S. H. (2001). Ground arthropod community

954 structure in a heterogeneous urban environment. Landscape and urban planning, 52(4), $257-274$.

955 McKinney, M. L. (2006). Urbanization as a major cause of biotichomogenization. Biological

956 conservation, 127(3), 247-260.

957 Meng, D., Gong, H., Li, X., Zhao, W., Gong, Z., Zhu, L., \& Hu, D. (2009, July). Study of

958 thermal environment based on remote sensing in Beijing-capital zone. In Geoscience and Remote

959 Sensing Symposium, 2009 IEEE International, IGARSS 2009(Vol. 3, pp. III-353). IEEE. 
960 Mikula, P., Hromada, M., \& Tryjanowski, P. (2013). Bats and swifts as food of the European

961 kestrel (Falco tinnunculus) in a small town in Slovakia. Ornis Fennica, 90(3), 178.

962 Mikula, P., Morelli, F., Lučan, R. K., Jones, D. N., \& Tryjanowski, P. (2016). Bats as prey of

963 diurnal birds: a global perspective. Mammal Review, 46 (3), 160-174.

964 Miller, J. R. (2005). Biodiversity conservation and the extinction of experience. Trends in 965 ecology \& evolution, 20(8), 430-434.

966 Miller, J. R., Fraterrigo, J. M., Hobbs, N. T., Theobald, D. M., \& Wiens, J. A. (2001).

967 Urbanization, avian communities, and landscape ecology. In Avian ecology and conservation in 968 an urbanizing world (pp. 117-137). Springer US.

969 Miller, M. W. (2006). Apparent effects of light pollution on singing behavior of American 970 robins. The Condor, 108(1), 130-139.

971 Mishra, N. B., \& Chaudhuri, G. (2015). Spatio-temporal analysis of trends in seasonal vegetation 972 productivity across Uttarakhand, Indian Himalayas, 2000-2014. Applied Geography, 56, 29-41.

973 Møller, A. P., Jokimäki, J., Skorka, P., \& Tryjanowski, P. (2014). Loss of migration and 974 urbanization in birds: a case study of the blackbird (Turdus merula). Oecologia, 175(3), 10199751027.

976 Møller, A. P., Díaz, M., Grim, T., Dvorská, A., Flensted-Jensen, E., Ibáñez-Álamo, J. D.,

977 Jokimäki, J., Mänd, R., Markó G., Szymański, P., \& Tryjanowski, P. (2015). Effects of

978 urbanization on bird phenology: a continental study of paired urban and rural

979 populations. Climate Research, 66(3), 185-199. 
980 Montaldo, N. H. (1984). Asociación de dos especies de picaflores con árboles del género

981 Eucalyptus (Myrtaceae) en la provincia de Buenos Aires. El Hornero, 12(03), 159-162.

982 Mulieri, P. R., Patitucci, L. D., Schnack, J. A., \& Mariluis, J. C. (2011). Diversity and seasonal 983 dynamics of an assemblage of sarcophagid Diptera in a gradient of urbanization. Journal of 984 Insect Science, 11(1).

985 Navara, K. J., \& Nelson, R. J. (2007). The dark side of light at night: physiological, 986 epidemiological, and ecological consequences. Journal of Pineal Research, 43(3), 215-224.

987 Negro JJ, J Bustamante, C Melguizo, JL Ruiz, JM Grande (2000) Nocturnal activity of lesser 988 kestrels under artificial lighting conditions in Seville, Spain. Journal of Raptor Research 34: 327989329.

990 Neil, K., \& Wu, J. (2006). Effects of urbanization on plant flowering phenology: a 991 review. Urban Ecosystems, 9(3), 243-257.

992 Neil, K., Wu, J., Bang, C., \& Faeth, S. (2014). Urbanization affects plant flowering phenology 993 and pollinator community: effects of water availability and land cover. Ecological 994 Processes, 3(1), 17.

995 Ockendon, N., Davis, S. E., Miyar, T., \& Toms, M. P. (2009). Urbanization and time of arrival 996 of common birds at garden feeding stations. Bird Study, 56(3), 405-410.

997 Olden, J. D., \& Rooney, T. P. (2006). On defining and quantifying biotic

998 homogenization. Global Ecology and Biogeography, 15(2), 113-120. 
999 Oro, D., Genovart, M., Tavecchia, G., Fowler, M. S., \& Martínez-Abraín, A. (2013). Ecological 1000 and evolutionary implications of food subsidies from humans. Ecology letters, 16(12), 150110011514.

1002 Palang H, Fry G, Jauhiainen JS, Jones M, Sooväli H (2005) Editorial: landscape and 1003 seasonality—seasonal landscapes. Landsc Res 30:165-172

1004 Palomino, D., \& Carrascal, L. M. (2006). Urban influence on birds at a regional scale: a case 1005 study with the avifauna of northern Madrid province. Landscape and Urban Planning, 77(3), $1006 \quad 276-290$.

1007 Parris, K. M. (2016). Ecology of Urban Environments. John Wiley \& Sons.

1008 Partecke, J., \& Gwinner, E. (2007). Increased sedentariness in European Blackbirds following 1009 urbanization: a consequence of local adaptation?. Ecology, 88(4), 882-890.

1010 Pau, S., Wolkovich, E. M., Cook, B. I., Davies, T. J., Kraft, N. J., Bolmgren, K., Betancourt, J. 1011 L., \& Cleland, E. E. (2011). Predicting phenology by integrating ecology, evolution and climate 1012 science. Global Change Biology, 17(12), 3633-3643.

1013 Pennington, D. N., Hansel, J., \& Blair, R. B. (2008). The conservation value of urban riparian 1014 areas for landbirds during spring migration: land cover, scale, and vegetation effects. Biological 1015 Conservation, 141(5), 1235-1248.

1016 Pickens, B. A., Marcus, J. F., Carpenter, J. P., Anderson, S., Taillie, P. J., \& Collazo, J. A. 1017 (2017). The effect of urban growth on landscape-scale restoration for a fire-dependent 1018 songbird. Journal of Environmental Management, 191, 105-115. 
1019 Plaza, P. I., \& Lambertucci, S. A. (2017). How are garbage dumps impacting vertebrate

1020 demography, health, and conservation?. Global ecology and conservation, 12, 9-20.

1021 Plummer, K. E., Siriwardena, G. M., Conway, G. J., Risely, K., \& Toms, M. P. (2015). Is

1022 supplementary feeding in gardens a driver of evolutionary change in a migratory bird

1023 species?. Global change biology, 21(12), 4353-4363.

1024 Pulgar, J., Zeballos, D., Vargas, J., Aldana, M., Manriquez, P., Manriquez, K., K., Quijón, P.A.,

1025 Widdicombe, S., Anguita, C., Quintanilla, D., \& Duarte, C. (2018). Endogenous cycles, activity

1026 patterns and energy expenditure of an intertidal fish is modified by artificial light pollution at

1027 night (ALAN). Environmental Pollution.

1028 Pyle, R.M. (1978) The extinction of experience. Horticulture 56: 64-67

1029 Ramírez-Segura, O. (2016). ¿Un inocente bocadito? Alimentando a las aves urbanas, revisión del 1030 caso de los colibríes. En Ramírez-Bautista A y Pineda-López R (Eds.) Fauna nativa en ambientes 1031 antropizados. CONACYT-UAQ, Querétaro, México.

1032 Recher, H. F., \& Serventy, D. L. (1991). Long term changes in the relative abundances of birds 1033 in Kings Park, Perth, Western Australia. Conservation Biology, 5(1), 90-102.

1034 Rejt, Ł. (2004). Nocturnal feeding of young by urban Peregrine Falcons (Falco peregrinus) in 1035 Warsaw (Poland). Polish Journal of Ecology, 52(1), 63-68.

1036 Reynolds, S. J., Galbraith, J. A., Smith, J. A., \& Jones, D. N. (2017). Garden bird feeding:

1037 insights and prospects from a north-south comparison of this global urban

1038 phenomenon. Frontiers in Ecology and Evolution, 5, 24. 
1039 Rizwan, A. M., Dennis, L. Y., \& Chunho, L. I. U. (2008). A review on the generation,

1040 determination and mitigation of Urban Heat Island. Journal of Environmental Sciences, 20(1),

$1041 \quad 120-128$.

1042 Rodewald, A. D., \& Shustack, D. P. (2008). Urban flight: understanding individual and

1043 population-level responses of Nearctic-Neotropical migratory birds to urbanization. Journal of

1044 Animal Ecology, 77(1), 83-91.

1045 Russ, A., Rüger, A., \& Klenke, R. (2015). Seize the night: European Blackbirds (Turdus merula)

1046 extend their foraging activity under artificial illumination. Journal of Ornithology, 156(1), 123-

1047131.

1048 Russ, A., Lučeničová, T., \& Klenke, R. (2017). Altered breeding biology of the European

1049 blackbird under artificial light at night. Journal of Avian Biology, 48(8), 1114-1125.

1050 Rutz, C. (2008). The establishment of an urban bird population. Journal of Animal

1051 Ecology, 77(5), 1008-1019.

1052 Sasaki, T., \& Lauenroth, W. K. (2011). Dominant species, rather than diversity, regulates the 1053 temporal stability of plant communities. Oecologia, 166(3), 761-768.

1054 Scanlon, A. T., \& Petit, S. (2008). Biomass and biodiversity of nocturnal aerial insects in an

1055 Adelaide City park and implications for bats (Microchiroptera). Urban Ecosystems, 11(1), 911056106.

1057 Schoener, T. W. (1974). Resource partitioning in ecological communities. Science, 185(4145), 1058 27-39. 
1059 Sekercioglu, C. H. (2006). Increasing awareness of avian ecological function. Trends in ecology

1060 \& evolution, 21(8), 464-471.

1061 Shanahan, D. F., Strohbach, M. W., Warren, P. S., \& Fuller, R. A. (2014). The challenges of

1062 urban living. Avian Urban Ecology (D. Gil and H. Brumm, Editors). Oxford University Press,

1063 Oxford, UK, 3-20.

1064 Shaw, L. M., Chamberlain, D., \& Evans, M. (2008). The House Sparrow Passer domesticus in

1065 urban areas: reviewing a possible link between post-decline distribution and human

1066 socioeconomic status. Journal of Ornithology, 149(3), 293-299.

1067 Shochat, E., Stefanov, W. L., Whitehouse, M. E. A., \& Faeth, S. H. (2004). Urbanization and 1068 spider diversity: influences of human modification of habitat structure and 1069 productivity. Ecological Applications, 14(1), 268-280.

1070 Shochat, E., Warren, P. S., Faeth, S. H., McIntyre, N. E., \& Hope, D. (2006). From patterns to 1071 emerging processes in mechanistic urban ecology. Trends in ecology \& evolution, 21(4), 1861072191.

1073 Shochat, E., Lerman, S. B., Anderies, J. M., Warren, P. S., Faeth, S. H., \& Nilon, C. H. (2010).

1074 Invasion, competition, and biodiversity loss in urban ecosystems. BioScience, 60(3), 199-208.

1075 Shukuroglou, P., \& Mccarthy, M. A. (2006). Modelling the occurrence of rainbow lorikeets

1076 (Trichoglossus haematodus) in Melbourne. Austral Ecology, 31(2), 240-253.

1077 Shutters, S. T., \& Balling, R. C. (2006). Weekly periodicity of environmental variables in 1078 Phoenix, Arizona. Atmospheric Environment, 40(2), 304-310. 
1079 Sick, H., \& Teixeira, D. M. (1981). Nocturnal activities of Brazilian hummingbirds and 1080 flycatchers at artificial illumination. The Auk, 98(1), 191-192.

1081 Soga, M., Gaston, K. J., Koyanagi, T. F., Kurisu, K., \& Hanaki, K. (2016). Urban residents' 1082 perceptions of neighbourhood nature: Does the extinction of experience matter? Biological 1083 Conservation, 203, 143-150.

1084 Sonne, J., Kyvsgaard, P., Maruyama, P. K., Vizentin-Bugoni, J., Ollerton, J., Sazima, M., 1085 Rahbek, C., \& Dalsgaard, B.. (2016). Spatial effects of artificial feeders on hummingbird 1086 abundance, floral visitation and pollen deposition. Journal of Ornithology, 157(2), 573-581.

1087 Stracey, C. M., Wynn, B., \& Robinson, S. K. (2014). Light pollution allows the Northern 1088 mockingbird (Mimus polyglottos) to feed nestlings after dark. Wilson Journal of 1089 Ornithology, 126(2), 366-369.

1090 Strubbe, D., \& Matthysen, E. (2009). Establishment success of invasive ring-necked and monk 1091 parakeets in Europe. Journal of Biogeography, 36(12), 2264-2278.

1092 Suarez-Rubio, M., Leimgruber, P., \& Renner, S. C. (2011). Influence of exurban development on 1093 bird species richness and diversity. Journal of Ornithology, 152(2), 461-471.

1094 Suhonen, J., Jokimäki, J., Kaisanlahti-Jokimäki, M. L., Hakkarainen, H., Huhta, E., Inki, K., \& 1095 Suorsa, P. (2009). Urbanization and stability of a bird community in winter. Ecoscience, 16(4), $1096 \quad 502-507$.

1097 Teglhøj, P. G. (2017). A comparative study of insect abundance and reproductive success of barn 1098 swallows Hirundo rustica in two urban habitats. Journal of Avian Biology 48(6), 846-853. 
1099 Thabethe, V., \& Downs, C. T. (2018). Citizen science reveals widespread supplementary feeding

1100 of African woolly-necked storks in suburban areas of KwaZulu-Natal, South Africa. Urban

1101 Ecosystems, 1-9.

1102 Thompson, P. S., Greenwood, J. J. D., \& Greenaway, K. (1993). Birds in European gardens in 1103 the winter and spring of 1988-89. Bird Study, 40(2), 120-134.

1104 Tomiałojć, L. (2011). Changes in breeding bird communities of two urban parks in Wrocław 1105 across 40 years (1970-2010): before and after colonization by important predators. Ornis 1106 Polonica, 52, 1-25.

1107 Tryjanowski, P., Skórka, P., Sparks, T. H., Biaduń, W., Brauze, T., Hetmański, T., Martyka, R., 1108 Indykiewicz, P., Myczko, L., Kunysz, P., Kawa, P., Czyż, S., Czechowski, P., Polakowski, M., 1109 Zduniak, P., Jerzak, L., Janiszewski, T., Goławski, A., Duduś, L., Nowakowski, J. J., 1110 Wuczyński, A., Wysocki, D. (2015). Urban and rural habitats differ in number and type of bird 1111 feeders and in bird species consuming supplementary food. Environmental Science and Pollution 1112 Research, 22(19), 15097-15103.

1113 Uchida, K., \& Ushimaru, A. (2015). Land abandonment and intensification diminish spatial and 1114 temporal $\beta$-diversity of grassland plants and herbivorous insects within paddy terraces. Journal 1115 of Applied Ecology, 52(4), 1033-1043.

1116 Uchida, K., Fujimoto, H., \& Ushimaru, A. (2018). Urbanization promotes the loss of seasonal 1117 dynamics in the semi-natural grasslands of an East Asian megacity. Basic and Applied 1118 Ecology, 29, 1-11. 
1119 Waide, R. B. (1991). The effect of Hurricane Hugo on bird populations in the Luquillo

1120 experimental forest, Puerto Rico. Biotropica, 23, 475-480.

1121 Waite, E., Closs, G. P., van Heezik, Y., \& Dickinson, K. J. (2013). Resource availability and

1122 foraging of Silvereyes (Zosterops lateralis) in urban trees. Emu-Austral Ornithology, 113(1), 26-

$1123 \quad 32$.

1124 Walcott, C. F. (1974). Changes in bird life in Cambridge, Massachusetts from 1860 to 1964. The 1125 Auk, 151-160.

1126 Warkentin, I. G., James, P. C., \& Oliphant, L. W. (1990). Body morphometrics, age structure, 1127 and partial migration of urban Merlins. The Auk, 25-34.

1128 Weaving, M. J., White, J. G., Isaac, B., \& Cooke, R. (2011). The distribution of three nocturnal 1129 bird species across a suburban-forest gradient. Emu-Austral Ornithology, 111(1), 52-58.

1130 Weller, A.A., Kirwan, G.M. \& Boesman, P. (2017). White-throated Hummingbird (Leucochloris 1131 albicollis). In: del Hoyo, J., Elliott, A., Sargatal, J., Christie, D.A. \& de Juana, E. (eds.).

1132 Handbook of the Birds of the World Alive. Lynx Edicions, Barcelona. (retrieved from 1133 http://www.hbw.com/node/55474 on 14 February 2017).

1134 Wenny, D. G., Devault, T. L., Johnson, M. D., Kelly, D., H. Sekercioglu, C., Tomback, D. F., \& 1135 Whelan, C. J. (2011). The need to quantify ecosystem services provided by birds. The 1136 auk, 128(1), 1-14.

1137 Williams, P. A., \& Karl, B. J. (1996). Fleshy fruits of indigenous and adventive plants in the diet 1138 of birds in forest remnants, Nelson, New Zealand. New Zealand Journal of Ecology, 127-145. 
1139 Williams, N. S., Mcdonnell, M. J., Phelan, G. K., Keim, L. D., \& Van Der Ree, R. (2006). Range

1140 expansion due to urbanization: Increased food resources attract Grey-headed Flying-foxes

1141 (Pteropus poliocephalus) to Melbourne. Austral Ecology, 31(2), 190-198.

1142 Yaukey, P. H. (2012). Population changes of urban land birds in the three years following the

1143 hurricane Katrina flood. Natural hazards, 61(3), 1203-1217.

1144 Yeh, P. J. (2004). Rapid evolution of a sexually selected trait following population establishment

1145 in a novel habitat. Evolution, 58(1), 166-174.

1146 Yorio, P., \& Giaccardi, M. (2002). Urban and fishery waste tips as food sources for birds in 1147 northern coastal Patagonia, Argentina. Ornitología Neotropical, 13, 283-292.

1148 Zhao, X., Yang, S., Shen, S., Hai, Y., \& Fang, Y. (2009). Analyzing the relationship between

1149 urban heat island and land use/cover changes in Beijing using remote sensing images. In Remote

1150 Sensing and Modeling of Ecosystems for Sustainability VI (Vol. 7454, p. 74541J). International

1151 Society for Optics and Photonics.

1152 Zheng, Q., Weng, Q., Huang, L., Wang, K., Deng, J., Jiang, R., Ye, Z., \& Gan, M. (2018). A

1153 new source of multi-spectral high spatial resolution night-time light imagery-JL1-3B. Remote

1154 Sensing of Environment, 215, 300-312.

1155 Zhou, D., \& Chu., L. M. (2012). How would size, age, human disturbance, and vegetation

1156 structure affect bird communities of urban parks in different seasons? Journal of Ornithology,

$1157 \quad 153,1101-1112$ 
1158 Zhou, D., Zhao, S., Zhang, L., \& Liu, S. (2016). Remotely sensed assessment of urbanization

1159 effects on vegetation phenology in China's 32 major cities. Remote Sensing of Environment, 176, $1160 \quad 272-281$.

1161

1162 


\section{Figure 1}

Schematic representation of intervening factors and possible mechanisms influencing the temporal dynamics of bird composition in urban areas.

Urbanization promotes the temporal stabilization of several environmental characteristics, such as light, food, temperature and habitat structure (red boxes and circles). Human disturbance, through the passing of pedestrians may provide food for birds, whereas the passing of cars may increase the urban heat island. Factors in circles may be strongly affected by the socioeconomical characteristics of citizens. The environmental stabilization is produced at different temporal scales (purple boxes), which in turn promote the temporal homogenization of bird communities. Dashed lines and boxes indicate factors and processes that require further research 


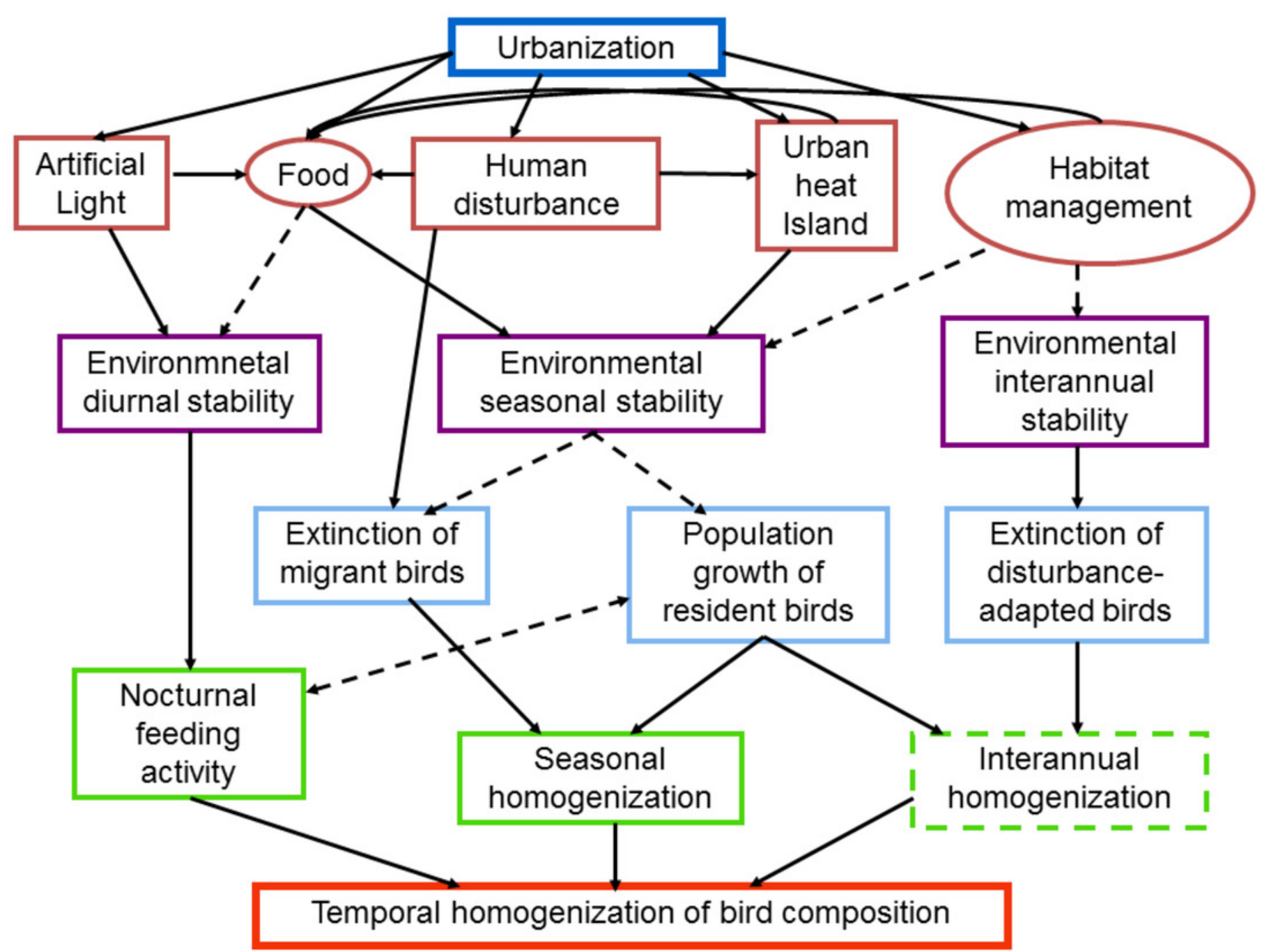




\section{Figure 2}

Non-metric multidimensional scaling showing the relationship between habitat types and the seasonal change of NDVI

The ordination was constructed with a matrix of percent cover of land cover types (vegetation and impervious surfaces) and the number of high trees $(<5 \mathrm{~m}$, Tree_more $5 \mathrm{~m})$ and low trees $(<5 \mathrm{~m}$, Tree_less $5 \mathrm{~m})$ as columns, and each sampling unit as rows. Then, a Gower dissimilitude distance was calculated. Finally, a surface of the seasonal change of NDVI (red lines with their values) was added to the ordination. The seasonal change is the mean NDVI of spring-summer minus the mean NDVI of fall-winter. Thicker lines indicate higher values of the seasonal change of NDVI. Modified from Leveau et al. (2018) 


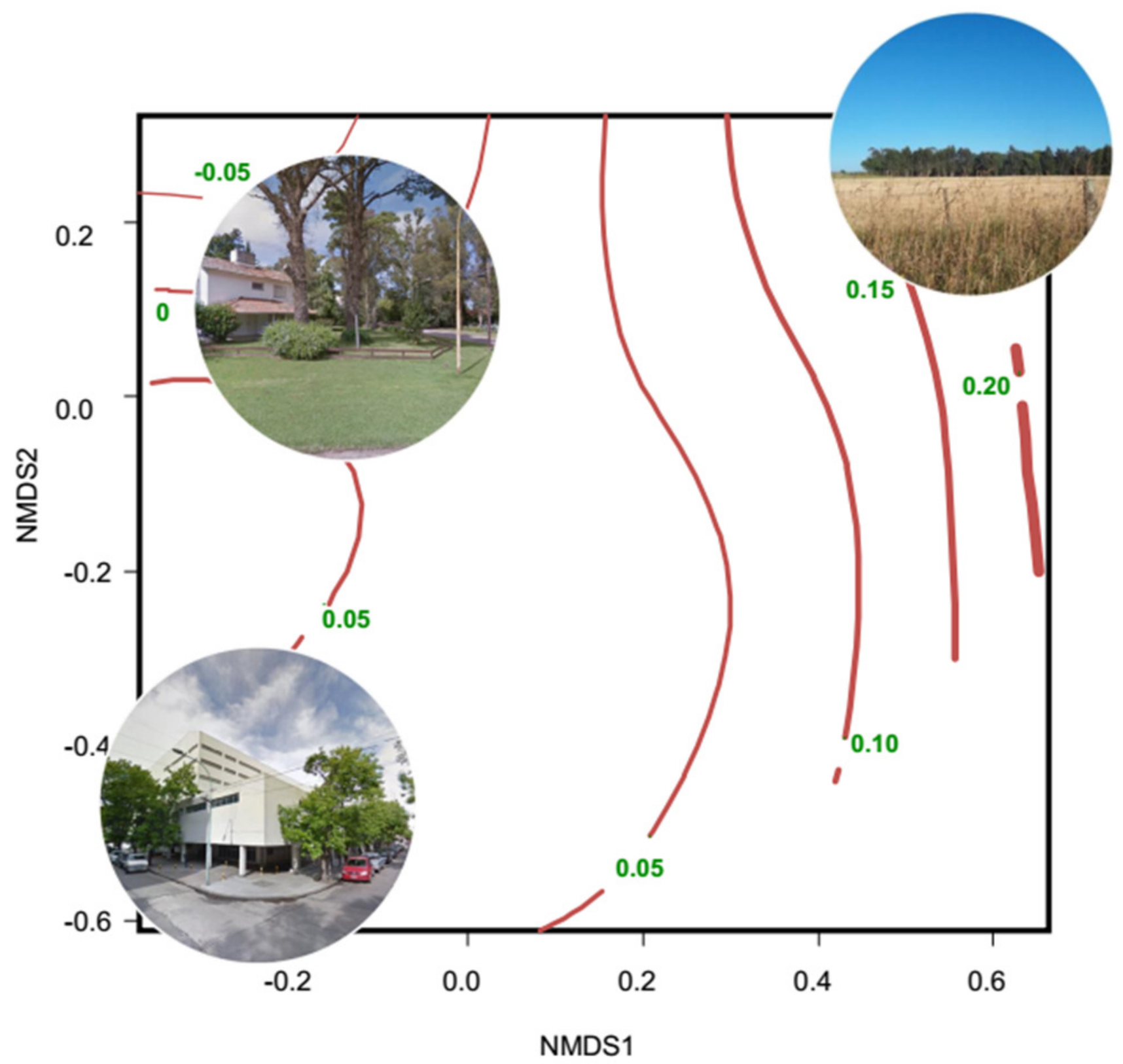




\section{Table $\mathbf{1}$ (on next page)}

Summary of studies assessing the nocturnal activity, such as feeding (A), singing (B) or both $(C)$ in relation to different artificial light intensities. 


\begin{tabular}{|c|c|c|c|}
\hline Species & Main results & Location & Source \\
\hline \multicolumn{4}{|l|}{ A- Feeding } \\
\hline Turdus merula & $\begin{array}{l}\text { Birds captured in the city started } \\
\text { their activity earlier than rural } \\
\text { birds }\end{array}$ & Munich, Germany & $\begin{array}{l}\text { Dominoni } \\
\text { et al. } 2013 b\end{array}$ \\
\hline Mimus polyglottos & $\begin{array}{l}\text { Birds fed nestlings after sunset in } \\
\text { areas with more artificial light }\end{array}$ & Gainesville, USA & $\begin{array}{l}\text { Stracey et } \\
\text { al. } 2014\end{array}$ \\
\hline Turdus merula & $\begin{array}{l}\text { Birds foraged after sunset in } \\
\text { areas with more artificial light }\end{array}$ & Leipzig, Germany & $\begin{array}{l}\text { Russ et al. } \\
2015\end{array}$ \\
\hline $\begin{array}{l}\text { Prunella modularis, Erithacus rubecula, Turdus merula, Cyanistes } \\
\text { caeruleus, Parus major, Pica pica, Passer domesticus, Fringilla coelebs, } \\
\text { Carduelis chloris }\end{array}$ & $\begin{array}{l}\text { Birds delayed the onset of } \\
\text { foraging in gardens surrounded } \\
\text { by more urbanization }\end{array}$ & UK & $\begin{array}{l}\text { Ockendon } \\
\text { et al. } 2009\end{array}$ \\
\hline Streptopelia decaocto & $\begin{array}{l}\text { Birds started earlier the onset of } \\
\text { foraging in gardens surrounded } \\
\text { by more urbanization }\end{array}$ & UK & $\begin{array}{l}\text { Ockendon } \\
\text { et al. } 2009\end{array}$ \\
\hline $\begin{array}{l}\text { Turdus merula, Erithacus rubecula, Cyanistes caeruleus, Prunella } \\
\text { modularis, Parus major, Fringilla coelebs, Periparus ater, Passer } \\
\text { domesticus, Caduelis carduelis, Columba palumbus } \\
\text { B- Singing }\end{array}$ & $\begin{array}{l}\text { Birds delayed the onset of } \\
\text { foraging in gardens with more } \\
\text { artificial light }\end{array}$ & UK & $\begin{array}{l}\text { Clewley et } \\
\text { al. } 2016\end{array}$ \\
\hline Columba palumbus & $\begin{array}{l}\text { Calling activity was not affected } \\
\text { by the distance to artificial light } \\
\text { source }\end{array}$ & $\begin{array}{l}\text { Greifswald, } \\
\text { Germany }\end{array}$ & $\begin{array}{l}\text { Böhm et al. } \\
2016\end{array}$ \\
\hline Turdus migratorius & $\begin{array}{l}\text { Birds sing at night in areas with } \\
\text { large amount of artificial light }\end{array}$ & Eastern USA & Miller 2006 \\
\hline Turdus merula, Erithacus rubecula, Parus major, Cyanistes caeruleus. & $\begin{array}{l}\text { Birds started singing earlier close } \\
\text { to artificial lights }\end{array}$ & Viena, Austria & $\begin{array}{l}\text { Kempenaer } \\
\text { s et al. } \\
2010\end{array}$ \\
\hline Fringilla coelebs & $\begin{array}{l}\text { Birds did not start singing earlier } \\
\text { close to artificial lights }\end{array}$ & Viena, Austria & $\begin{array}{l}\text { Kempenaer } \\
\text { s et al. } \\
2010\end{array}$ \\
\hline $\begin{array}{l}\text { Turdus merula, Fringilla coelebs, Parus major, Cyanistes caeruleus, } \\
\text { Erithacus rubecula }\end{array}$ & $\begin{array}{l}\text { Birds started singing earlier close } \\
\text { to artificial lights }\end{array}$ & $\begin{array}{l}\text { Oulu, Finland; } \\
\text { Starnberg, } \\
\text { Germany; Granada, } \\
\text { Spain }\end{array}$ & $\begin{array}{l}\text { Da Silva } \\
\text { and } \\
\text { Kempenaer } \\
\text { s } 2017\end{array}$ \\
\hline
\end{tabular}


C - Feeding and singing

Pyrocephalus rubinus

Birds sang and foraged at night in Morelia, Mexico areas with more artificial light

Birds sang and foraged at night close to artificial light
MacGregor

-Fors et al.

2011

Byrkjedal

et al. 2012

1 


\section{Table 2 (on next page)}

Summary of studies that compared the seasonal change of bird composition along urbanization gradients. 


\begin{tabular}{|c|c|c|c|}
\hline Location & Main results & Periods compared & Source \\
\hline Montpellier, France & $\begin{array}{l}\text { The lowest seasonal turnover was shown in the most urbanized } \\
\text { areas, but residential areas had lowest }\end{array}$ & winter-spring & Caula et al. 2008 \\
\hline North America & $\begin{array}{l}\text { The lowest seasonal change was shown in urban habitats; there } \\
\text { was a greater effect in the west than in east NA }\end{array}$ & monthly & La Sorte et al. 2014 \\
\hline $\begin{array}{l}\text { Mar del Plata, } \\
\text { Argentina }\end{array}$ & $\begin{array}{l}\text { The lowest seasonal change was shown in areas with more } \\
\text { impervious cover }\end{array}$ & breeding-nonbreeding & Leveau et al. 2015 \\
\hline $\begin{array}{l}\text { Mar del Plata, } \\
\text { Argentina }\end{array}$ & $\begin{array}{l}\text { The lowest seasonal change was shown in urban parks of the } \\
\text { urban center }\end{array}$ & breeding-nonbreeding & $\begin{array}{l}\text { Leveau and Leveau } \\
2016\end{array}$ \\
\hline
\end{tabular}

1 


\section{Table 3(on next page)}

Summary of studies that compared the interannual change of bird composition along urbanization gradients. 


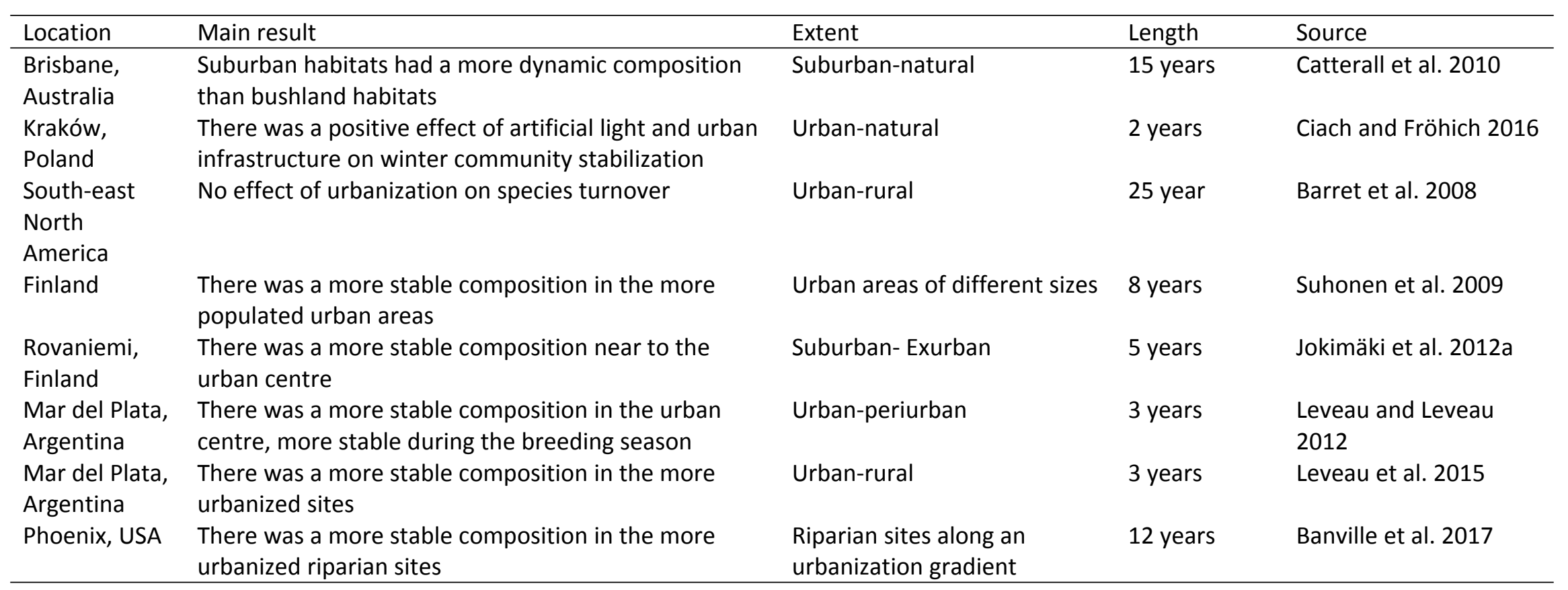

1 